\title{
Laminar Burning Velocity of Biogas-Containing Mixtures. A Literature Review
}

\author{
Venera Giurcan, Codina Movileanu, Adina Magdalena Musuc (D) and Maria Mitu *(D) \\ “Ilie Murgulescu" Institute of Physical Chemistry, Romanian Academy, 202 Spl. Independentei, \\ 060021 Bucharest, Romania; venerab@icf.ro (V.G.); cmovileanu@icf.ro (C.M.); amusuc@icf.ro (A.M.M.) \\ * Correspondence: maria_mitu@icf.ro
}

Citation: Giurcan, V.; Movileanu, C.; Musuc, A.M.; Mitu, M. Laminar Burning Velocity of Biogas-Containing Mixtures. A Literature Review. Processes 2021, 9 996. https://doi.org/10.3390/ pr9060996

Academic Editor: Albert Ratner

Received: 22 April 2021

Accepted: 2 June 2021

Published: 4 June 2021

Publisher's Note: MDPI stays neutral with regard to jurisdictional claims in published maps and institutional affiliations.

Copyright: (c) 2021 by the authors. Licensee MDPI, Basel, Switzerland. This article is an open access article distributed under the terms and conditions of the Creative Commons Attribution (CC BY) license (https:// creativecommons.org/licenses/by/ $4.0 /)$.
Abstract: Currently, the use of fossil fuels is very high and existing nature reserves are rapidly depleted. Therefore, researchers are turning their attention to find renewable fuels that have a low impact on the environment, to replace these fossil fuels. Biogas is a low-cost alternative, sustainable, renewable fuel existing worldwide. It can be produced by decomposition of vegetation or waste products of human and animal biological activity. This process is performed by microorganisms (such as methanogens and sulfate-reducing bacteria) by anaerobic digestion. Biogas can serve as a basis for heat and electricity production used for domestic heating and cooking. It can be also used to feed internal combustion engines, gas turbines, fuel cells, or cogeneration systems. In this paper, a comprehensive literature study regarding the laminar burning velocity of biogas-containing mixtures is presented. This study aims to characterize the use of biogas as IC (internal combustion) engine fuel, and to develop efficient safety recommendations and to predict and reduce the risk of fires and accidental explosions caused by biogas.

Keywords: biogas; oxygen addition; hydrogen addition; laminar burning velocity; experimental and computing methods

\section{Introduction}

Energy based on fossil fuel consumption is the basis of industrial and economic development. The current fossil fuel utilisation is rapidly depleting the natural reserves. Therefore, researchers are currently turning their attention to find renewable fuels having a low impact on the environment to replace these depleting fossil fuels. The major challenge for scientists and engineers in addition to optimisation of engine combustion, improving fuel economy and lower pollutant emissions, is to find alternative-fuels able to maintain outstanding performance, durability, and reliability of engines at an affordable price. One of the alternative fuels tested and used successfully is biogas.

Biogas is a low-cost alternative, sustainable, renewable fuel existing worldwide produced by microorganisms, such as methanogens and sulfate-reducing bacteria, performing anaerobic respiration. Biogas can refer to gas produced naturally or industrially from decomposition of vegetation or waste products of human and animal biological activity. Because it is a natural by-product, biogas is one of the non-exhaustible supplies in the world. The environmental benefit by producing energy from biogas is deeply appreciated through the reduction of gas emissions that exhibit a greenhouse effect by preventing its release into the atmosphere. Even if the biogas has a low heating value (about $3000-6000 \mathrm{kcal} / \mathrm{m}^{3}$ ) compared to natural gas (about $8000-9000 \mathrm{kcal} / \mathrm{m}^{3}$ ) or liquefied petroleum gas (about $25,000-28,000 \mathrm{kcal} / \mathrm{m}^{3}$ ), its total chemical energy is sufficient to serve as a basis for the production of the heat and electricity that can be further used for domestic heating and cooking, or to feed internal combustion engines, gas turbines, fuel cells, or cogeneration systems [1-5]. A schematic diagram for biogas production and its applications is given in Figure 1. 


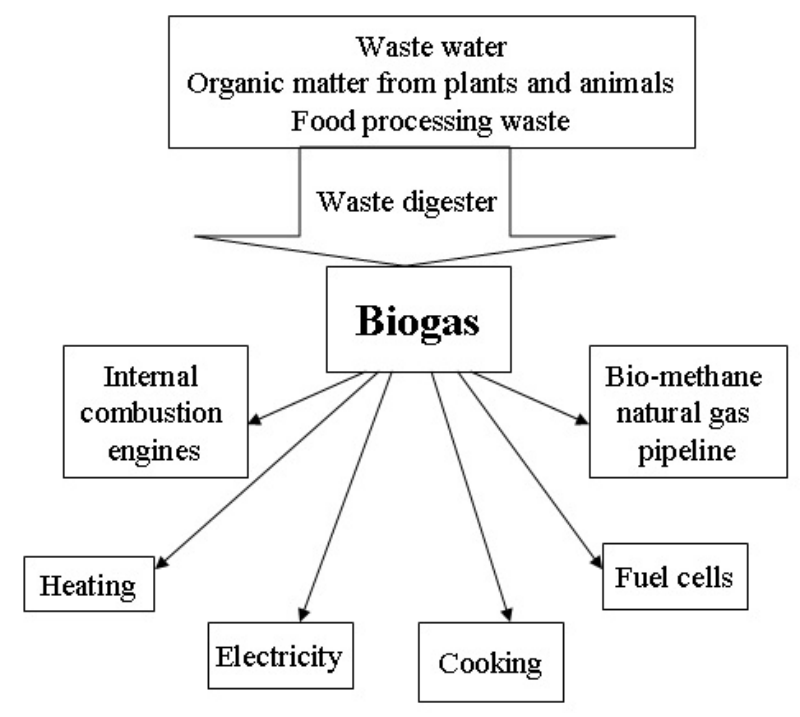

Figure 1. Schematic diagram for biogas production and applications.

The composition of biogas varies depending upon the substrate composition, as well as the conditions within the anaerobic reactor (temperature, $\mathrm{pH}$, and substrate concentration) [6]. Biogas is a mixture mainly consisting of methane and carbon dioxide in different molar fractions, depending on the preparation method. The composition of biogas is approximately $70 \% \mathrm{CH}_{4}-30 \% \mathrm{CO}_{2}$, with traces of $\mathrm{H}_{2} \mathrm{~S}, \mathrm{H}_{2}, \mathrm{NH}_{3}$ and $\mathrm{H}_{2} \mathrm{O}_{\text {vap. The most }}$ important component of biogas, from the calorific perspective, is methane, $\mathrm{CH}_{4}$, which is a very flammable fuel. $\mathrm{CO}_{2}$ and $\mathrm{H}_{2} \mathrm{O}_{\text {vap }}$ have a diluting effect on the mixture composition and reduce the flammability range. Besides $\mathrm{CO}_{2}$ and $\mathrm{H}_{2} \mathrm{O}_{\text {vap }}, \mathrm{N}_{2}$ from the air contributes to diluting the mixture and therefore can reduce considerably the biogas explosivity. The presence of multiple diluting agents hinders the prediction of the whole flammability envelope since each inert gas has its own inerting power when mixed with methane [7].

Unfortunately, fires and accidental explosions involving biogas could occur [8-11]. Therefore, a strict determination of the explosion parameters of biogas-air mixtures has a great practical interest for mitigation of incidents associated with gaseous explosions and for evaluating safe conditions of running reactors or plants where flammable mixtures are formed.

Scientific contributions regarding biogas explosions are available in the literature [12-19]. Some of them report values of flammability parameters of synthetic biogas (flammability limits, limiting oxygen concentration, maximum explosion pressure and maximum rate of pressure rise) [14,15], while others report laminar burning velocities from measurements or kinetic modelling [17,20-24]. Recent studies regarding synthetic biogas-air mixtures [25,26], $\mathrm{CH}_{4}$-air-inert mixtures [27-31], and $\mathrm{CH}_{4}$-nitrous oxide-inert mixtures [32,33] were performed under various initial conditions to obtain the laminar burning velocities. The investigation on the effect of concentration of methane in biogas when it is used as a fuel for a spark ignition engine was reported by Porpatham et al. [34]. Other studies revealed the effect of additives $\left(\mathrm{N}_{2}, \mathrm{Ar}, \mathrm{H}_{2} \mathrm{O}\right.$ or $\left.\mathrm{CO}_{2}\right)$ on $\mathrm{CH}_{4} /$ air, $\mathrm{CH}_{4} / \mathrm{CO}_{2} /$ air and $\mathrm{CH}_{4} / \mathrm{O}_{2} / \mathrm{H}_{2} /$ inert flames [35-41]. The attention of other researchers has been directed towards the combustion characteristics of biogas under hydrogen-enriched conditions [24,42-49]. In some experiments, realised in a spark ignition engine, small $\mathrm{H}_{2}$ amounts were added to biogas to enhance engine performance and reduce pollutant emissions [16,50-53]. The effects of oxygen-enriched air on the operation and performance of a diesel-biogas dual fuel engine were also presented by Cacua et al. [54]. Other studies on biogas combustion in the presence of oxygen-enriched air were presented by $\mathrm{Li}$ et al. [42]; Oh and Noh [55]; Cardona and Amell [56]; Navarro-Puyuelo et al. [57]; Striūgas et al. [58]; Wang et al. [59].

Biogas (alone or blended with other fuels) is used as fuel in internal combustion engines, which are the main power source for transport vehicles and commonly used for 
powering generators of electrical energy $[4,5,60]$. Therefore, it is necessary to study its combustion properties such as the explosion pressure, severity factor and laminar burning velocity. The last one is the most important parameter that describes the combustion process. Laminar burning velocity represents a unique characteristic of a gaseous mixture with fixed composition, initial temperature and pressure. This parameter adequately describes the essential characteristics of the fuel-oxidizer mixtures regarding thermal diffusivity, exothermicity, and reactivity. On a practical level, this parameter affects the fuel burning rate in internal combustion engines and the engine's performance and emissions. On a fundamental level, the laminar burning velocity is an important target for kinetic mechanism development and validation. Accurate determination of laminar burning velocity is extremely important for the development and validation of kinetic mechanisms for gasoline, diesel surrogate fuels and alternative fuels [60-62].

The state of the art, the challenges of combustion chemistry research, the flammability limits, the impact of carbon dioxide on the laminar burning velocity and stability of the flame for biogas-air mixtures were reviewed by Wang et al. [4] and Pizzuti et al. [60,62]. In the present paper, a comprehensive study of the literature regarding the laminar burning velocity of biogas-containing mixture is presented aiming to characterize the use of biogas as internal combustion engine fuel, of the necessity to develop new safety measures for handling, storage and use of these mixtures and to predict and reduce the risks associated with fires and explosions.

\section{General Characteristics of Flames in Gaseous Mixtures. The Laminar Burning Velocity}

A flame is the result of a self-sustaining chemical reaction usually made visible by the luminosity of the burning gases. Associated with a flame is the flame front, in which the unburnt gas is heated and converted into products. Whether the flame is stationary or moving in space, the movement of the flame front, which is of finite thickness, is taken as an indication of the progress of the flame [63]. The flames can be laminar or turbulent. The laminar flames have been studied extensively in laboratories as they can provide the most detailed information about combustion chemistry and various physical effects that act upon the flame [64].

The laminar burning velocity is an important intrinsic property of a combustible mixture. It is defined as the speed at which an adiabatic, unstretched, premixed planar flame propagates relative to the unburned mixture [65]. The laminar burning velocity is a physico-chemical property of a premixed fuel-oxidizer mixture, resulting from the combined influence of the mixture diffusivity, exothermicity and reactivity $[66,67]$. It affects or even determines the burning rate of fuel-air mixtures in practical combustion systems. The laminar burning velocity provides a measure of overall reactivity of fuel-air mixtures and helps in determining the rates of heat release and in testing and validating the detailed reaction mechanisms and simplified kinetic models. Laminar burning velocity is a key parameter that also helps describe various combustion phenomena such as flame stabilisation, flame flash back, flame blow out, and flame extinction $[67,68]$. The laminar burning velocity as a parameter appears in the modelling of various combustion phenomena and in the development of surrogate fuel models [69], in the prediction of pollutant formation through detailed mechanisms and in the accurate modelling of the combustion of fuel-oxidizer mixture under practical conditions, i.e., in combustion systems such as industrial furnaces, internal combustion engines, gas turbine combustors and rocket engines $[67,70,71]$. Although the laminar burning velocity is not a measurable quantity and is derived from other observables using different assumptions or theoretical models, this important parameter is used for scaling and modelling of the turbulent combustion flames.

The laminar burning velocity by definition is the velocity of a free flame propagating in the doubly infinite domain configuration and corresponds to the velocity at which the fresh premixed gas makes a planar flame steady. Therefore, this definition makes it suitable for calculations by 1-D computer codes using kinetic models, thermodynamic and transport properties as input parameters and hence leads to the validation of the 
kinetic schemes. It is, however, unfeasible to perform experiments with planar flames in the doubly infinite domain from both obvious practical and fundamental points of view. The non-quiescent unburned gas mixtures affect the planar flame propagation inside a confined space due to thermal expansion, flame wall interactions, acoustic pressure waves and buoyancy effects $[72,73]$. One of the main problems in measuring the laminar burning velocity is that a plane flame front can be observed only under special conditions.

\section{Experimental Methods for Determining the Laminar Burning Velocity}

Researchers from the combustion field have developed many experimental techniques to obtain the laminar burning velocity of fuel-air mixtures. The experimental techniques for laminar burning velocities determination, described in present work, are resumed in Table 1. The experiments realised on biogas-containing mixtures were made using both stationary and non-stationary flames. The stationary flames were studied by (a) burner method using Bunsen burners $[38,45,48,74,75]$ or flat flames burners $[24,59,76-78]$ or (b) the counter-flow twin flames method [79]. The non-stationary flames were studied by the constant volume method using cylindrical $[22,23,26,44,46,80-82]$ or spherical vessels $[5,20,21,25,81,83,84]$.

Table 1. Experimental techniques for laminar burning velocities determination described in present work.

\begin{tabular}{|c|c|c|c|c|}
\hline Flame Type & Experir & al Method & Flame Monitoring & Initial Conditions \\
\hline \multirow{3}{*}{ Stationary } & \multirow{2}{*}{ Burner method } & Bunsen burner & Schlieren photography & $\begin{array}{l}\text { Various pressures and } \\
\text { compositions }\end{array}$ \\
\hline & & Flat flame burner & Schlieren photography & $\begin{array}{l}\text { Over the whole } \\
\text { flammability range }\end{array}$ \\
\hline & \multicolumn{2}{|c|}{ Counter-flow twin flames } & $\begin{array}{l}\text { Dopler velocimetry particle } \\
\text { Imaging velocimetry }\end{array}$ & $\begin{array}{l}\text { Various pressures and } \\
\text { temperatures }\end{array}$ \\
\hline \multirow{2}{*}{ Non-stationary } & \multirow{2}{*}{ Spherical flames } & $\begin{array}{l}\text { Constant volume } \\
\text { method }\end{array}$ & $\begin{array}{l}\text { Schlieren photography } \\
\text { Pressure transducers } \\
\text { Ionization gauges } \\
\text { High speed camera }\end{array}$ & $\begin{array}{c}\text { Various compositions, } \\
\text { pressures and } \\
\text { temperatures }\end{array}$ \\
\hline & & $\begin{array}{l}\text { Constant pressure } \\
\text { method }\end{array}$ & $\begin{array}{l}\text { Schlieren photography } \\
\text { Pressure transducers } \\
\text { Ionization gauges } \\
\text { High speed camera }\end{array}$ & $\begin{array}{l}\text { Various compositions } \\
\text { and temperatures }\end{array}$ \\
\hline
\end{tabular}

The Bunsen burner method is a simple method to measure the laminar burning velocity for a conical flame [85]. The method offers the possibility of obtaining the laminar burning velocities over various initial compositions and pressures. This method involves calculating the laminar burning velocities from photographs or tracings considering the volume rate of flow through the section of the flame surface being constant. A simple relation to obtain the laminar burning velocity, $S_{u}$, is:

$$
S_{u}=v_{0} \cdot \sin \left(\frac{\alpha_{0}}{2}\right)
$$

where $v_{0}$ represents the gas flow velocity in the central area of the burner tube and $\alpha_{0}$ represents the angle of the cone formed by the front of the flame. However, the errors made in measuring of the laminar burning velocity are large, and the correct assessment of either the area of the flame front or the angle $\alpha_{0}$ is difficult. In addition, it has been realised $[86,87]$ that Bunsen flames are affected by different factors such as flame instability, stretch, curvature and heat loss. A schematic representation of the Bunsen burner is presented in Figure 2a. 


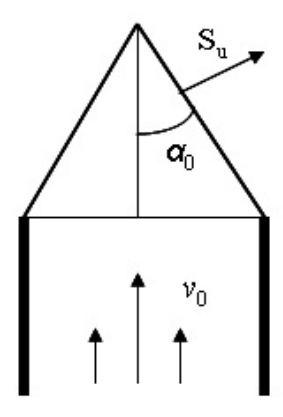

(a)

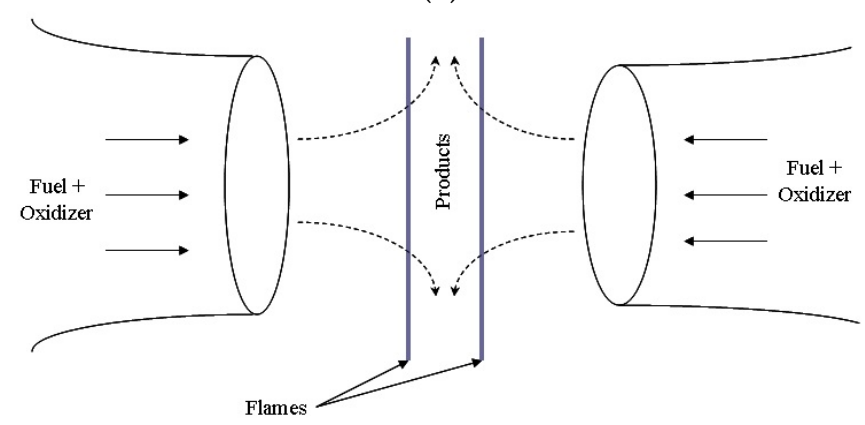

(c)

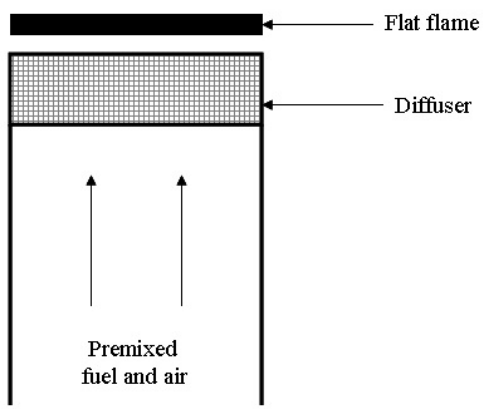

(b)

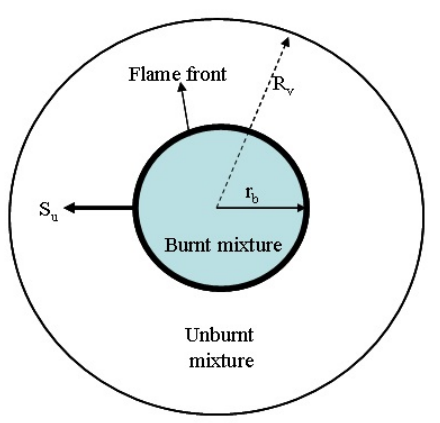

(d)

Figure 2. Schematic representation of different experimental methods: (a) Bunsen burner; (b) Flat flame burner; (c) Counterflow twin flames; (d) Closed vessel method.

The flat flame burner is obtained by mounting a "diffuser" to the ordinary burner that creates a constant profile of the gas flow rate, thus obtaining a flat flame. This method is used at low gas flow rates allowing to measure small values of the laminar burning velocities that occur in mixtures with the composition close to the explosion limit [88]. An interesting feature of this method is the appearance of an intense heat transfer between the flame and burner, which makes the explosive mixture suffer an appreciable preheating. Thermostating the upper part of the burner affords to maintain the unburned gas at the desired temperature and offers the possibility to achieve reproducible conditions for the production of these stationary flames. In addition, the introduction of the burner in an enclosure filled with inert gas allows measurements of normal combustion rates at different initial pressures and thus offers a considerable extension of this method. A schematic representation of the flat flame burner is presented in Figure $2 b$.

In the Figure $2 \mathrm{c}$ a diagram of the counter-flow twin flames method is presented. This method consists of two symmetric (twin) and planar flames generated on either side of a stagnation plane, at an offset distance, with the same chemical composition. This method has been used in the past in the laboratories being the most sensitive method regarding the changes in the flow characteristics [89-91]. The axial velocity profile is determined using different optical techniques such as laser Doppler velocimetry or particle image velocimetry. The advantage of this method is that the influence of stretch on the flame speed can be quantified and extracted by using the procedure proposed by Wu and Law [90]. However, it is difficult to use this method at pressures above $5 \mathrm{~atm}$ [64].

Another method used for determining the laminar burning velocity of biogas-air mixtures is the constant volume method, which measures the flame radius and/or pressure rise in the explosion vessel. At the early stage of flame propagation, the temperature gradients in both unburned and burned gas are small and can be neglected. Additionally, the flame remains spherical and the heat losses do not influence its development. For a given mixture, the flame speed can be obtained from a single test over a wide range of temperatures and pressures. Although the method has many advantages, it is found that the stretch effect is proportional to the Markstein length and inversely proportional to the 
flame size. Furthermore, for mixtures with Lewis numbers greatly deviating from unity, the stretch effect on flame speed is significant [92]. This method is suitable for laminar burning velocity measurements at high pressures and temperatures, which are close to relevant conditions from internal combustion engines and gas turbines [93,94]. To capture the images with the spherical expanding flames, the Schlieren measurement technique can be applied or a high-speed camera can be coupled to the experimental set-up. Records of the pressure and flame radius are used along with adequate correction procedures meant to consider the flame stretch $[73,95]$. The laminar burning velocity, $S_{u}$, can be obtained from pressure-time records by using specific equations. One of them is that which uses the cubic law coefficient of pressure rise $(k)$ in the early stage of the flame propagation in a closed vessel by assuming isothermal compression of unburned gas ahead the flame front [96]:

$$
S_{u}=R_{v}\left(\frac{k}{\Delta p_{\max }}\right)^{\frac{1}{3}}\left(\frac{p_{0}}{p_{\max }}\right)^{\frac{2}{3}}
$$

In Equation (2) $R_{v}$ is the radius of the explosion vessel; $\Delta p_{\max }$ is the peak pressure rise of the explosion at the initial pressure $p_{0}$; and $p_{\max }=\Delta p_{\max }+p_{0}$.

A diagram of the closed vessel method is drawn in the Figure $2 \mathrm{~d}$.

A comparison of experimental methods for determining the laminar burning velocity described in the present paper is given in Table 2.

Table 2. Comparison of experimental methods for determining the laminar burning velocity described in the present work.

\begin{tabular}{|c|c|c|c|}
\hline Method & & Advantage & Disadvantage \\
\hline Bunsen burner [85] & - & $\begin{array}{l}\text { a simple method to } \\
\text { measure the laminar } \\
\text { burning velocity for a } \\
\text { conical flame; } \\
\text { laminar burning velocities } \\
\text { obtained over various } \\
\text { initial compositions and } \\
\text { pressures. }\end{array}$ & $\begin{array}{l}\text { - } \quad \text { the measuring of laminar } \\
\text { burning velocity is affected } \\
\text { by large errors; } \\
\text { flames are affected by } \\
\text { flame instability, stretch, } \\
\text { curvature and heat loss; } \\
\text { - } \quad \text { lack of uniformity of the } \\
\text { burning velocity over the } \\
\text { flame surface; } \\
\text { unburnt gas temperature } \\
\text { profile is difficult to } \\
\text { establish. }\end{array}$ \\
\hline Flat flame burner [88] & - & $\begin{array}{l}\text { a simple method to } \\
\text { measure the laminar } \\
\text { burning velocity for a flat } \\
\text { flame; } \\
\text { provides a close } \\
\text { approximation to the ideal } \\
\text { one-dimensional flat flame; } \\
\text { laminar burning velocities } \\
\text { obtained over various } \\
\text { initial pressures and } \\
\text { compositions. }\end{array}$ & 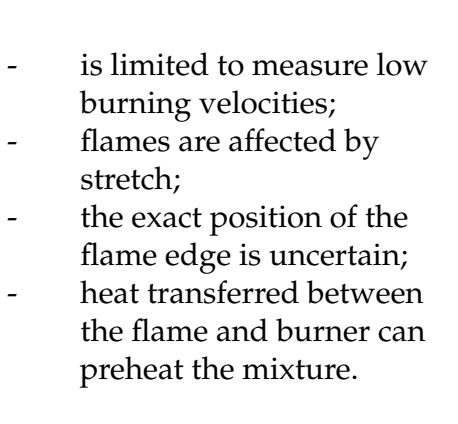 \\
\hline
\end{tabular}


Table 2. Cont.

\begin{tabular}{|c|c|c|}
\hline Method & Advantage & Disadvantage \\
\hline $\begin{array}{l}\text { Counter-flow twin } \\
\text { flames [89-91] }\end{array}$ & $\begin{array}{l}\text { - } \quad \text { the most sensitive method } \\
\text { regarding the changes in } \\
\text { the flow characteristics; } \\
\text { two symmetric (twin) and } \\
\text { planar flames with the } \\
\text { same chemical composition } \\
\text { are used; } \\
\text { velocity profile can be } \\
\text { determined using optical } \\
\text { techniques (Doppler } \\
\text { velocimetry or particle } \\
\text { image velocimetry); } \\
\text { flame stretch is quantified } \\
\text { and extracted using a } \\
\text { dedicated procedure. }\end{array}$ & $\begin{array}{l}\text { - } \\
\text { the method is difficult to } \\
\text { use at pressures above } 5 \\
\text { atm; } \\
\text { the uncertainty in laminar } \\
\text { burning velocity due to } \\
\text { thermocouple } \\
\text { measurements depends on } \\
\text { the rate of heat production } \\
\text { in the flame. }\end{array}$ \\
\hline $\begin{array}{c}\text { Closed vessel method } \\
\text { [93-96] }\end{array}$ & 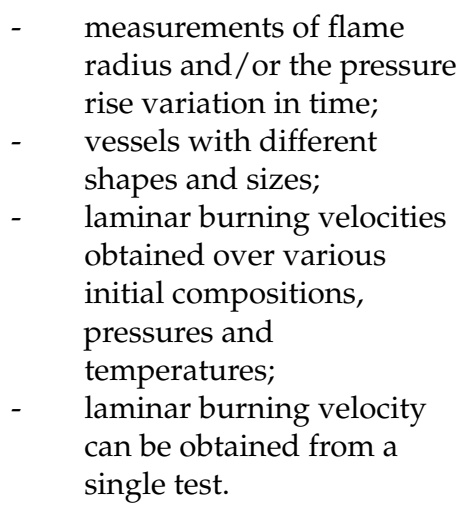 & 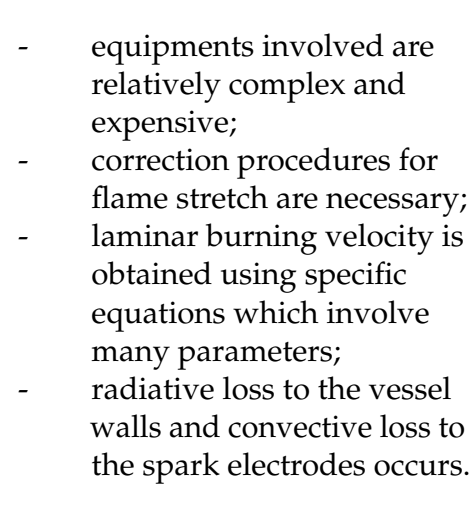 \\
\hline
\end{tabular}

More details regarding the accuracy, uncertainties, strengths and weaknesses of these methods can be found in the review papers of Egolfopoulos et al. [64], Konnov et al. [73] and Faghih and Chen [93].

\section{Computing Methods}

The laminar burning velocities of biogas-air flames can be obtained from the computation on one-dimensional freely propagating flames using different dedicated programs and various mechanisms, at various initial conditions (initial temperature and pressure, fuel concentration, diluent concentration). These numerical calculations are required to validate the experimental results. Computing programs try simulating the reaction pathways using one or more kinetic mechanisms. There are some programs for kinetic modelling of the combustion, many of them being suitable for methane combustion.

For biogas-containing mixtures, several authors used the CHEMKIN package together with GRI-Mech mechanism (version 2.11 or 3.0) [22-24,26,41,45,56,74-76,81,97] while other authors used USC Mech II mechanism [22,79]; San Diego mechanism [23,24]; C1-C3 mechanism [56] or Le Cong mechanism [77].

Goodwin et al. [98] used the CANTERA code and three chemical kinetic mechanisms: GRI-Mech 3.0, USC Mech II and San Diego mechanism.

Another set of papers reports laminar burning velocities obtained from simulations performed using the REGATH package [39] or COSILAB package [29,99] with GRI 3.0 chemical scheme.

The GRI Mechanism (versions 2.11 or 3.0) is an optimized mechanism designed to model natural gas combustion, which includes NO formation and reburn chemistry. 
This mechanism provides sound basic kinetics that also furnish the best combined modeling predictability of basic combustion properties. The GRI-Mech 3.0 mechanism [100] can be adjusted to methane combustion at various initial pressures (between 0.1 and 10 bar) and is based on 53 species (including argon) and 325 chemical reactions.

The USC Mech II mechanism considers 111 species and 784 chemical reactions relevant to C1-C4 hydrocarbons and syngas oxidation at high temperature [101]. It applies to a wide variety of combustion scenarios, incorporating the recent thermodynamic, kinetic, and species transport updates relevant to high-temperature oxidation of hydrogen, carbon tmonoxide, and $\mathrm{C} 1-\mathrm{C} 4$ hydrocarbons.

The San Diego mechanism is optimised for autoignition and diffusive flames of different hydrocarbons and considers 37 species and 177 chemical reactions [102]. It applies to various experimental conditions: temperatures between $1000 \mathrm{~K}$ and $3000 \mathrm{~K}$; pressures up to $10 \mathrm{~atm}$; equivalence ratios between 0.5 and 2.0.

Qin et al. [103] developed the C1-C3 mechanism for combusting light hydrocarbons such as $\mathrm{CH}_{4}, \mathrm{C}_{2} \mathrm{H}_{4}, \mathrm{C}_{2} \mathrm{H}_{6}, \mathrm{C}_{3} \mathrm{H}_{4}, \mathrm{C}_{3} \mathrm{H}_{6}$ and $\mathrm{C}_{3} \mathrm{H}_{8}$ optimising the rate parameters of 258 reactions. This detailed chemical reaction mechanism is conceptually structured hierarchically with $\mathrm{H}_{2}$ and $\mathrm{CO}$ chemistry at the base, supplemented by elementary reactions of larger chemical species.

The Le Cong mechanism consists of 18 species and 66 reactions, as described by Le Cong et al. [104,105]. This mechanism is used to simulate the one-dimensional freely propagating flame, determining the premixed, laminar flame speed of the gaseous mixtures. It is designed for modelling the oxidation of hydrogen, $\mathrm{CO}$, methane, methanol, formaldehyde, and natural gas over a wide range of conditions, including jet-stirred reactor, flame, shock tube, and plug flow reactor.

The Konnov mechanism used in [78] consists of 127 species and 1027 reactions. It is a detailed reaction mechanism, which accurately describes pyrolysis, ignition, oxidation and detonation of many small hydrocarbons and nitrogen-containing fuels reacting with different oxidizers over a wide range of conditions typical for combustion processes.

\section{Initial Conditions of Studied Biogas-Air Mixtures}

Whether the studies reported in the literature on laminar burning velocity of biogas-air mixtures were conducted experimentally or by numerical modelling, these were performed at various initial pressures (ranging from 0.5 to 18 bar), temperatures (between 295 and $661 \mathrm{~K}$ ), and compositions (equivalence ratios ranging from 0.4 to 1.6 and $\mathrm{CO}_{2}$ dilution between 0 and $70 \%)$.

All of the aforementioned conditions for obtaining the laminar burning velocity of biogas-air blends, described in the present work, are summarised in Table 3.

Table 3. Initial conditions for obtaining the laminar burning velocities of biogas-air and synthetic biogas $\left(\mathrm{CH}_{4} / \mathrm{CO}_{2}\right)$-air flames described in the present work.

\begin{tabular}{|c|c|c|c|c|}
\hline Author & $\begin{array}{l}\text { Equivalence Ratio, } \\
\varphi\end{array}$ & $\begin{array}{c}\text { Initial Pressure, } \\
p_{0}\end{array}$ & $\begin{array}{c}\text { Initial Temperature, } \\
T_{0}\end{array}$ & $\begin{array}{c}{\left[\mathrm{CO}_{2}\right]} \\
\%\end{array}$ \\
\hline Anggono et al. [20,21,26,84] & $0.5-1.4$ & $0.5 ; 1 ; 3$ bar & $298 \mathrm{~K}$ & 30.6 \\
\hline Pituzzi et al. [23] & $0.7-1.1$ & $1-5$ bar & $298 \mathrm{~K}$ & $35-55$ \\
\hline Yadav et al. [24] & $0.7-1.4$ & 1 bar & $298 \mathrm{~K}$ & $5-50$ \\
\hline Hinton and Stone [25] & $0.7-1.4$ & $1-18$ bar & $380-660 \mathrm{~K}$ & $0-40$ \\
\hline Mitu et al. [29] & $0.6-1.3$ & $0.5-2$ bar & $298 \mathrm{~K}$ & $0-17.5$ \\
\hline Cohé et al. [38] & 0.6 & 1-9 bar & $298 \mathrm{~K}$ & $0-40$ \\
\hline Patino et al. [39] & $0.7-1.3$ & 1 bar & $298 \mathrm{~K}$ & $0-50$ \\
\hline Ren et al. [41] & $0.8-1.2$ & 1 bar & $398 \mathrm{~K}$ & $0-40$ \\
\hline Acero-Caballero et al. $[43,45]$ & $1.0-1.1$ & 1 bar & $298 \mathrm{~K}$ & $34-40$ \\
\hline Suhaimi et al. [44] & $0.4-0.9$ & 1 bar & $300 \mathrm{~K}$ & 50 \\
\hline Wei et al. [46] & $0.9-1.3$ & 1 bar & $298 \mathrm{~K}$ & $40-60$ \\
\hline Nurmukan et al. [48] & $0.8-1.3$ & 1 bar & $298-440 \mathrm{~K}$ & $30-40$ \\
\hline Quintino et al. [49] & $0.8-1.0$ & 1 bar & $298 \mathrm{~K}$ & $0-20$ \\
\hline
\end{tabular}


Table 3. Cont.

\begin{tabular}{|c|c|c|c|c|}
\hline Author & $\begin{array}{l}\text { Equivalence Ratio, } \\
\varphi\end{array}$ & $\begin{array}{c}\text { Initial Pressure, } \\
p_{0}\end{array}$ & $\begin{array}{c}\text { Initial Temperature, } \\
T_{0}\end{array}$ & $\begin{array}{c}{\left[\mathrm{CO}_{2}\right]} \\
\%\end{array}$ \\
\hline Cardona and Amell [56] & $0.6-1.5$ & 0.85 bar & $295 \mathrm{~K}$ & 34 \\
\hline Hu et al. $[74,75]$ & $0.6-1.4$ & 1 bar & $300 ; 400 ; 543 \mathrm{~K}$ & $25 ; 35$ \\
\hline Kishore et al. [76] & $0.8-1.3$ & $1 \mathrm{bar}$ & $307 \mathrm{~K}$ & $0-60$ \\
\hline Chan et al. [77] & $0.8-1.4$ & 1 bar & $298 \mathrm{~K}$ & $0-15$ \\
\hline Nonaka and Pereira [78] & $0.7-1.4$ & 1 bar & $298 \mathrm{~K}$ & $0-50$ \\
\hline Park et al. [79] & $0.75-1.25$ & $1 ; 2 ; 4$ bar & $298 \mathrm{~K}$ & $25 ; 45$ \\
\hline Halter et al. [80] & 1.0 & 1 bar & $300 \mathrm{~K}$ & $0-20$ \\
\hline Xie et al. [81] & $0.4-1.6$ & $1 ; 2 ; 3$ bar & $300 \mathrm{~K}$ & $0-60$ \\
\hline Bai et al. [82] & $0.8-1.2$ & $0.5-6.9 \mathrm{bar}$ & $298-661 \mathrm{~K}$ & $0-60$ \\
\hline Stone et al. [83] & $0.6-1.4$ & $0.5-10.4$ bar & $295-454 \mathrm{~K}$ & $0-60$ \\
\hline Zahedi and Yousefi [97] & $0.7-1.3$ & $1-5$ bar & $298 \mathrm{~K}$ & $0-20$ \\
\hline Boushaki et al. [99] & $0.7-1.3$ & 1 bar & $298 \mathrm{~K}$ & $0-50$ \\
\hline Zhen et al. [106] & $0.8-1.2$ & 1 bar & $298 \mathrm{~K}$ & $40-60$ \\
\hline Qin et al. [107] & $0.65-0.75$ & 1 bar & $300 \mathrm{~K}$ & $0-50$ \\
\hline
\end{tabular}

\section{Discussions}

\subsection{Laminar Burning Velocities of Biogas-Air Flames}

When compared to methane, biogas has narrower flammability limits, a lower heating value and lower burning velocity, mainly due to the presence of a high amount of carbon dioxide. Moreover, biogas is resistant to self-ignition due to its higher auto-ignition temperature [34]. Therefore, biogas presents certain problems related to flame instability when it is used in conventional combustion systems. To understand and avoid such problems, the laminar burning velocities of biogas-air mixtures (either synthetic biogas or not) were studied by many authors, using different experimental and/or numerical methods. The experimental and numerical methods for obtaining the laminar burning velocity of biogas-air mixtures used in the present paper are summarised in Table 4.

Stone et al. [83] reported data from experiments in a closed vessel for several composition of biogas $\left(80 \% \mathrm{CH}_{4}-20 \% \mathrm{CO}_{2} ; 67 \% \mathrm{CH}_{4}-33 \% \mathrm{CO}_{2} ; 50 \% \mathrm{CH}_{4}-50 \% \mathrm{CO}_{2} ; 40 \% \mathrm{CH}_{4}-60 \%\right.$ $\mathrm{CO}_{2}$ ), at 1 bar and $298 \mathrm{~K}$ under microgravity conditions. They developed a correlation for the laminar burning velocity of $\mathrm{CH}_{4}-\mathrm{CO}_{2}$-air blends with various equivalence ratios. The correlation was applied for concentrations of $\mathrm{CO}_{2}$ up to $60 \%$, initial pressures of up to 10 bar and initial temperatures up to $494 \mathrm{~K}$. For the stoichiometric mixture and ambient initial conditions, the laminar burning velocity of biogas composition of $80 \% \mathrm{CH}_{4}-20 \%$ $\mathrm{CO}_{2}$ was found to be $31.5 \mathrm{~cm} / \mathrm{s}$; for $50 \% \mathrm{CH}_{4}-50 \% \mathrm{CO}_{2}$ the laminar burning velocity was found to be $17.7 \mathrm{~cm} / \mathrm{s}$, while for $40 \% \mathrm{CH}_{4}-60 \% \mathrm{CO}_{2}$ the laminar burning velocity was reported $13.0 \mathrm{~cm} / \mathrm{s}$.

Ju et al. [108] determined the laminar burning velocities of synthetic mixtures (equivalence ratio $0.5-1.0)$ of $\mathrm{CH}_{4}$ and $\mathrm{CO}_{2}\left(\mathrm{CO}_{2}: 10,20\right.$ and $\left.30 \mathrm{vol} \%\right)$ by kinetic modelling, adopting two models: the optically thin model and the heat reabsorption model. The last model considers the spectral radiation in the one-dimensional coordinate of heat reabsorption from $\mathrm{H}_{2} \mathrm{O}$ and $\mathrm{CO}_{2}$ that approximately halves the net heat loss and lead to reduce the lower flammability limit and influence the laminar burning velocity. A good agreement between experiments and data from reabsorption model was found.

The laminar burning velocities of $\mathrm{CH}_{4}-\mathrm{CO}_{2}$-air mixtures with various equivalence ratios $(0.65-0.75)$ and $\mathrm{CO}_{2}$ content up to $50 \mathrm{vol} \%$ were experimentally and numerically determined, at atmospheric pressure, using a stagnation-flow experimental configuration and the detailed GRI 2.11 chemical kinetic mechanism [107]. The results indicate that, for the same equivalence ratio, addition of $\mathrm{CO}_{2}$ to the fuel significantly reduces the laminar burning velocity. For example, for a flame with equivalence ratio of 0.75 , when the carbon dioxide content varies from 0 to $50 \%$, the experimental value of laminar burning velocity decreases from $23.5 \mathrm{~cm} / \mathrm{s}$ (mixtures without $\mathrm{CO}_{2}$ ) to $13.0 \mathrm{~cm} / \mathrm{s}$ (mixtures with $50 \%$ 
$\mathrm{CO}_{2}$ ). The experimentally measured laminar burning velocities were, in general, in good agreement with the predicted values.

Table 4. Summary of experimental and computed methods for obtaining the laminar burning velocity of biogas-air mixtures presented in the present study.

\begin{tabular}{|c|c|c|c|}
\hline Type of Method & \multicolumn{2}{|c|}{ Method/Model/Mechanism Name } & Reference \\
\hline \multirow{5}{*}{ Experimental } & \multicolumn{2}{|c|}{ Bunsen burner } & Cohé et al. [38] \\
\hline & \multicolumn{2}{|c|}{ Contoured slot burner } & Cardona and Amell [56] \\
\hline & \multicolumn{2}{|c|}{ Flat flame burner } & $\begin{array}{c}\text { Kishore et al. [76] } \\
\text { Chan et al. [77] } \\
\text { Nonaka and Pereira [78] } \\
\text { Zahedi and Yousefi [97] } \\
\text { Qin et al. [107] }\end{array}$ \\
\hline & \multicolumn{2}{|c|}{ Counter-flow twin flames } & Park et al. [79] \\
\hline & \multicolumn{2}{|c|}{ Closed vessel } & $\begin{array}{c}\text { Anggono et al. } \\
\text { [20,21,26,84] } \\
\text { Pituzzi et al. [23] } \\
\text { Hinton and Stone [25] } \\
\text { Mitu et al. [29] } \\
\text { Halter et al. [80] } \\
\text { Bai et al. [82] } \\
\text { Stone et al. [83] }\end{array}$ \\
\hline \multirow{15}{*}{ Numerical } & \multirow{4}{*}{ CHEMKIN software } & GRI-Mech 2.11 & Cardona and Amell [56] \\
\hline & & GRI-Mech. 3.0 & $\begin{array}{c}\text { Anggono et al. [26] } \\
\text { Cohé et al. [38] } \\
\text { Ren et al. [41] } \\
\text { Halter et al. [80] } \\
\text { Zahedi and Yousefi [97] }\end{array}$ \\
\hline & & $\mathrm{C}_{1}-\mathrm{C}_{3}$ mechanism & Cardona and Amell [56] \\
\hline & & Le Cong mechanism & Chan et al. [77] \\
\hline & Cantera package & GRI-Mech. 3.0 & Bai et al. [82] \\
\hline & \multirow{4}{*}{ 1D Premix code } & GRI-Mech 2.11 & Qin et al. [107] \\
\hline & & GRI-Mech. 3.0 & $\begin{array}{l}\text { Pituzzi et al. [23] } \\
\text { Kishore et al. [76] }\end{array}$ \\
\hline & & $\begin{array}{l}\text { USC-Mech } 2.0 \\
\text { mechanism }\end{array}$ & Park et al. [79] \\
\hline & & San Diego mechanism & Pituzzi et al. [23] \\
\hline & \multirow{4}{*}{ Chem1D code } & GRI-Mech. 3.0 & Nonaka and Pereira [78] \\
\hline & & $\begin{array}{l}\text { USC-Mech } 2.0 \\
\text { mechanism }\end{array}$ & Nonaka and Pereira [78] \\
\hline & & San Diego mechanism & Nonaka and Pereira [78] \\
\hline & & Konnov mechanism & Nonaka and Pereira [78] \\
\hline & REGATH package & GRI-Mech. 3.0 & Patino et al. [39] \\
\hline & COSILAB code & GRI-Mech. 3.0 & $\begin{array}{c}\text { Mitu et al. [29] } \\
\text { Boushaki et al. [99] }\end{array}$ \\
\hline
\end{tabular}

A study by Kishore et al. [76] focused on the determination of the laminar burning velocity of natural gas by the heat flux method. This study presented the effects of $\mathrm{CO}_{2}$ $(0-60 \%)$ on flame properties at various equivalence ratios $(0.8-1.3)$, temperature of $307 \mathrm{~K}$, and atmospheric pressure. Computations were also conducted using the steady onedimensional laminar premixed flame code PREMIX, together with GRI-Mech 3.0 reaction 
mechanism. At the stoichiometric equivalence ratio, the experimental laminar burning velocity decreases from $30.7 \mathrm{~cm} / \mathrm{s}$ for mixtures containing $20 \mathrm{vol} \% \mathrm{CO}_{2}$ to $23.5 \mathrm{~cm} / \mathrm{s}$ for mixtures with $40 \% \mathrm{CO}_{2}$ and to $14.5 \mathrm{~cm} / \mathrm{s}$ for mixtures containing $60 \% \mathrm{CO}_{2}$. The numerical results agree well with the experimental data for mixtures with high content of carbon dioxide compared to the mixtures with $20 \mathrm{vol} \% \mathrm{CO}_{2}$.

An experimental study on a lean $\mathrm{CH}_{4}-\mathrm{CO}_{2}$-air mixture (equivalence ratio equal to 0.6), with different carbon dioxide content (up to $40 \%$ ), at various initial pressures, was conducted using both, laminar and turbulent Bunsen flame configurations [38]. Data provided by Chemkin package using GRI-Mech 3.0 mechanism complete the experimental results. All data indicated a decrease of the laminar burning velocities with increasing $\mathrm{CO}_{2}$ dilution rate. The effect of initial pressure on laminar burning velocities was found to be more pronounced than the carbon dioxide content. Moreover, the computations slightly underestimate the reduction of laminar burning velocity caused by the $\mathrm{CO}_{2}$ content.

The laminar burning velocities of biogas-air mixtures (composition of biogas: $55 \%$ $\mathrm{CH}_{4}-45 \% \mathrm{CO}_{2} ; 75 \% \mathrm{CH}_{4}-25 \% \mathrm{CO}_{2}$ ) were studied experimentally and numerically in the counter-flow configuration at various initial equivalence ratios (between 0.7-1.3), initial pressures ranging from 1 to $4 \mathrm{~atm}$, and ambient initial temperature [79]. The laminar burning velocity is reduced with pressure and $\mathrm{CO}_{2}$ content increase. The experimental values of laminar burning velocity for stoichiometric mixtures, at standard conditions, are $21.7 \mathrm{~cm} / \mathrm{s}$ for biogas composition of $55 \% \mathrm{CH}_{4}-45 \% \mathrm{CO}_{2}$ and $29.5 \mathrm{~cm} / \mathrm{s}$ for biogas composition of $75 \% \mathrm{CH}_{4}-25 \% \mathrm{CO}_{2}$. The numerical simulations with PREMIX code and USC Mech II kinetic model reproduced closely the experimental values of the laminar burning velocities over all experimental conditions.

Spherically expanding flames propagating at constant pressure were employed to determine the laminar burning velocity and flammability characteristics of biogas-air mixtures [20,21]. The composition of biogas consisted from $66.4 \%$ methane, $30.6 \%$ carbon dioxide and $3 \%$ nitrogen. The laminar burning velocities were measured at various equivalence ratios (0.5-1.3), at room temperature and atmospheric and sub-atmospheric pressure ( 0.5 bar). For the ambient initial conditions and equivalence ratio of 1.0, the authors reported a laminar burning velocity of $26.4 \mathrm{~cm} / \mathrm{s}$. They found that at sub-atmospheric initial pressure the diffusion time of reactants decreases and consequently, the laminar burning velocity becomes higher than that at atmospheric pressure.

Cardona and Amell [56] measured the laminar burning velocity for biogas-air mixture $\left(66 \% \mathrm{CH}_{4}-34 \% \mathrm{CO}_{2}\right)$ and biogas- $\mathrm{C}_{3} \mathrm{H}_{8}-\mathrm{H}_{2}$ mixture $\left(33 \% \mathrm{CH}_{4}-17 \% \mathrm{CO}_{2}-40 \% \mathrm{C}_{3} \mathrm{H}_{8}-10 \% \mathrm{H}_{2}\right)$ with normal and oxygen-enriched air, at 0.828 bar and $295 \mathrm{~K}$, for various equivalence ratios (0.6-1.5). For the stoichiometric biogas-air mixture, they found that the laminar burning velocity is $28.5 \mathrm{~cm} / \mathrm{s}$. The GRI-Mech 3.0 and $\mathrm{C}_{1}-\mathrm{C}_{3}$ reaction mechanisms were used to perform numerical simulations. They observed that the predictions of the GRI-Mech 3.0 mechanism agree quite well the experimental results, except those of oxygen-enriched biogas combustion, where the differences can be due to the high amount of $\mathrm{CO}_{2}$ in the fuel mixture. The $C_{1}-C_{3}$ reaction mechanism underestimates the laminar burning velocities at all studied mixtures.

Results for higher pressures (up to 18 bar), temperatures (up to $660 \mathrm{~K}$ ) and equivalence ratios in the range $0.7-1.4$ have been obtained using the pressure rise method in a constant volume [25]. A correlation with twelve coefficients fitted the results. The data showed a decrease in the laminar burning velocity with initial pressure and an increase with initial temperature. For the stoichiometric mixture and standard conditions the laminar burning velocity for $60 \% \mathrm{CH}_{4-} 40 \% \mathrm{CO}_{2}$ is $22.5 \mathrm{~cm} / \mathrm{s}$ wile for $80 \% \mathrm{CH}_{4-} 20 \% \mathrm{CO}_{2}$ is $29.5 \mathrm{~cm} / \mathrm{s}$.

Nonaka and Pereira [78] experimentally measured the laminar burning velocity of biogas and calculated it for various $\mathrm{CO}_{2}$ concentrations (0-50\%). The experiments were undertaken using the heat flux method, at $298 \mathrm{~K}$ and $1 \mathrm{bar}$, and were supplemented with data from numerical modelling using four detailed reaction mechanisms: San Diego, USC-Mech II, GRI-Mech 3.0 and Konnov. Their results showed that carbon dioxide presence reduces the laminar burning velocity and that the shifting of the maximum burning velocity 
towards leaner mixtures is determined by a combination of $\mathrm{CO}_{2}$ dilution and reaction effects. For the most studied composition of biogas $\left(60 \% \mathrm{CH}_{4}-40 \% \mathrm{CO}_{2}\right)$, the experimental values of laminar burning velocity vary from $16 \mathrm{~cm} / \mathrm{s}$ for a lean mixture (equivalence ratio 0.8 ) to $22.0 \mathrm{~cm} / \mathrm{s}$ for the stoichiometric mixture, and to $13.0 \mathrm{~cm} / \mathrm{s}$ for a rich mixture (equivalence ratio 1.3). The results obtained using the GRI-Mech 3.0 mechanism agreed well with measurements for mixtures with $10 \%$ and $20 \% \mathrm{CO}_{2}$. For mixtures with $30 \%$, 40\% and $50 \% \mathrm{CO}_{2}$, the Konnov mechanism presented the best agreement with the experimental data.

Another study [84] was conducted in a spherical closed vessel to find the effect of $\mathrm{CO}_{2}$ on biogas laminar burning velocities at various initial pressures and equivalence ratios (0.5-1.4) and ambient initial temperature. The composition of $\mathrm{CO}_{2}$ was 25 and 50\%, respectively. The results showed that the laminar burning velocity, at the same equivalence ratio and initial pressure, declined in respect with the increased level of carbon dioxide. For example, for the stoichiometric mixtures at atmospheric initial pressure, the laminar burning velocity is $28.9 \mathrm{~cm} / \mathrm{s}$ for mixture with $25 \% \mathrm{CO}_{2}$ and $18.9 \mathrm{~cm} / \mathrm{s}$ for mixture with $50 \% \mathrm{CO}_{2}$.

Carbon dioxide dilution on the laminar burning velocity of methane-air mixture was studied using kinetic modelling to understand the effect of $\mathrm{CO}_{2}$ concentrations ( 0 to $50 \mathrm{vol} \%$ ) on the combustion characteristics of biogas [39]. The simulations were performed using the REGATH package with GRI 3.0 chemical scheme. The computations on mixtures with equivalence ratios from 0.7 to 1.3 were made at initial pressure of 1 bar and an inlet temperature of $298 \mathrm{~K}$. The results showed that increase in $\mathrm{CO}_{2}$ concentrations reduced the concentrations of the reactants, decreasing the net reaction rate and thus the flame speed.

Pituzzi et al. [23] studied the laminar burning velocity of twelve synthetic biogas mixtures in a closed vessel. Initial pressure between 1 and 5 bar, equivalence ratios between 0.7 and 1.1, and a percentage dilution of a mixture of $\mathrm{CO}_{2}$ and $\mathrm{N}_{2}$ between 35 and $55 \%$, have been considered. A comparison with simulation using PREMIX for both GRI-Mech 3.0 and San Diego mechanisms has provided closer agreement for mixtures with the equivalence ratio closer to the stoichiometry, whereas for the equivalence ratio of 0.7 the deviation is larger than $15 \%$ for all pressures. The authors noted that the lower values of laminar burning velocity were recorded for the mixtures with lower equivalence ratio, higher dilution percentage and higher initial pressure.

A study was conducted by Anggono et al. [26] on the stoichiometric mixture using both numerical and experimental methods. The experiments were made in a closed combustion chamber under various initial mixture pressures ( 1 bar and 3 bar), $298 \mathrm{~K}$ and $\mathrm{CO}_{2}$ concentrations up to $70 \%$ to simulate the conditions of a combustor working at high pressure conditions. In addition, numerical simulations were carried by CHEMKIN-PRO package with GRI-Mech 3.0 employed as mechanism. The results showed that the laminar burning velocity of methane-air mixtures decreased with an increase in $\mathrm{CO}_{2}$ concentration and mixture pressure. At $70 \% \mathrm{CO}_{2}$ the experimental laminar burning velocity at 1 bar is $8.0 \mathrm{~cm} / \mathrm{s}$, while at 3 bar decrease to $4.3 \mathrm{~cm} / \mathrm{s}$. The experimental and computed data agree well.

Bai et al. [82] studied the laminar burning velocities of biogas over various initial temperatures (300-661 K), pressures (0.5-6.9 bar) and equivalence ratios (0.8-1.2) with four different $\mathrm{CO}_{2}$ concentrations $(0 \%, 20 \%, 40 \%$, and $60 \%)$ using the closed vessel method. Based on the measured laminar burning velocities, two power law correlations for two concentrations of carbon dioxide have been developed. The experimental laminar burning velocities have been compared with the simulation results of Cantera software with GRIMech 3.0 mechanism. The comparison showed a good agreement between experimental and computed data. The authors concluded that both pressure and $\mathrm{CO}_{2}$ concentration present negative effect on the laminar burning velocity. Alternatively, temperature positively affects the laminar burning velocity. They also mention that there is a peak value of laminar burning velocities for each $\mathrm{CO}_{2}$ concentration, and the equivalence ratios related to the maximum burning velocity shift to lean mixtures with increasing $\mathrm{CO}_{2}$ concentration. It is also found that the equivalence ratios of the peak burning velocities with low $\mathrm{CO}_{2}$ 
concentrations (0-20\%) do not change. For high $\mathrm{CO}_{2}$ concentrations (40-60\%), the equivalence ratios at maximum burning velocity shift towards lean mixtures with increasing temperature. The experimental laminar burning velocities of stoichiometric biogas-air mixtures, at standard conditions, obtained by Bai et al. [82] are $30.5 \mathrm{~cm} / \mathrm{s}$ for $20 \% \mathrm{CO}_{2}$; $22.3 \mathrm{~cm} / \mathrm{s}$ for $40 \% \mathrm{CO}_{2} ; 13.0 \mathrm{~cm} / \mathrm{s}$ for $60 \% \mathrm{CO}_{2}$.

Numerical calculations of biogas-air flames are performed using the 1-D COSILAB code using GRI-Mech 3.0 mechanism [99]. Calculations include laminar flame velocity, flame temperature and $\mathrm{CO}-\mathrm{NO}_{x}$ emissions with different parameters, such as temperature and pressure of fresh gases, equivalence ratio and gas composition. Several reaction mechanisms were used and compared to the results from the literature. The runs were performed for equivalence ratios between 0.7 and $1.3, \mathrm{CO}_{2}$ content up to $50 \mathrm{vol} \%, 298 \mathrm{~K}$ and 1 bar. Results showed that calculations with some of these mechanisms reproduce well experimental results of the literature. But also that, $\mathrm{CO}_{2}$ addition induces a decrease in laminar burning velocity, an increase in $\mathrm{CO}$ emissions and a decrease in $\mathrm{NO}_{\mathrm{x}}$ formation.

The effects of adding $\mathrm{CO}_{2}$ on the laminar premixed combustion characteristics of methane were simulated using the premixed free-propagating flame model based on the CHEMKIN II taken into account the Soret effect [41]. The GRI-Mech 3.0 mechanism was selected to analyse the laminar premixed combustion characteristics of the mixtures with different $\mathrm{CO}_{2}$ dilutions ( $(0-40 \mathrm{vol} \%)$ and equivalence ratios (0.8, 1.0 and 1.2), at an initial temperature of $398 \mathrm{~K}$ and an initial pressure of 1 bar. The authors concluded that both the physical and chemical effects of $\mathrm{CO}_{2}$ reduce the laminar burning velocity. The physical effects are greater than the chemical effects.

The variation of the laminar burning velocities of biogas-air mixtures with various equivalence ratios, at different $\mathrm{CO}_{2}$ content and standard initial conditions compiled from the above studies are given in Figure 3 for experimental data and in Figure 4 for numerical modelling. As we expected, the dependence of the laminar burning velocity on the biogas composition has the shape of a parabola with the concavity orientated towards the axis of the composition. For the mixtures with higher content of carbon dioxide (e.g., $60 \% \mathrm{vol}$ ), the maximum of the parabola is not recorded at the stoichiometric composition corresponding to the complete combustion of the biogas to $\mathrm{CO}_{2}$ and $\mathrm{H}_{2} \mathrm{O}$, but at mixtures with a concentration slightly higher than the stoichiometric concentration. For the mixtures with lower $\mathrm{CO}_{2}$ content (such as $20 \% \mathrm{vol}$ ) the maximum of the parabola is recorded at stoichiometric mixture, no matter if the data are obtained from measurements or computation. For the same initial conditions (composition, pressure and temperature), the maximum value of laminar burning velocity corresponds to the maximum value of flame temperature. At this moment the maximum amount of heat is released by the fuel mixture, according to the competition between exothermic and endothermic processes within the flame.

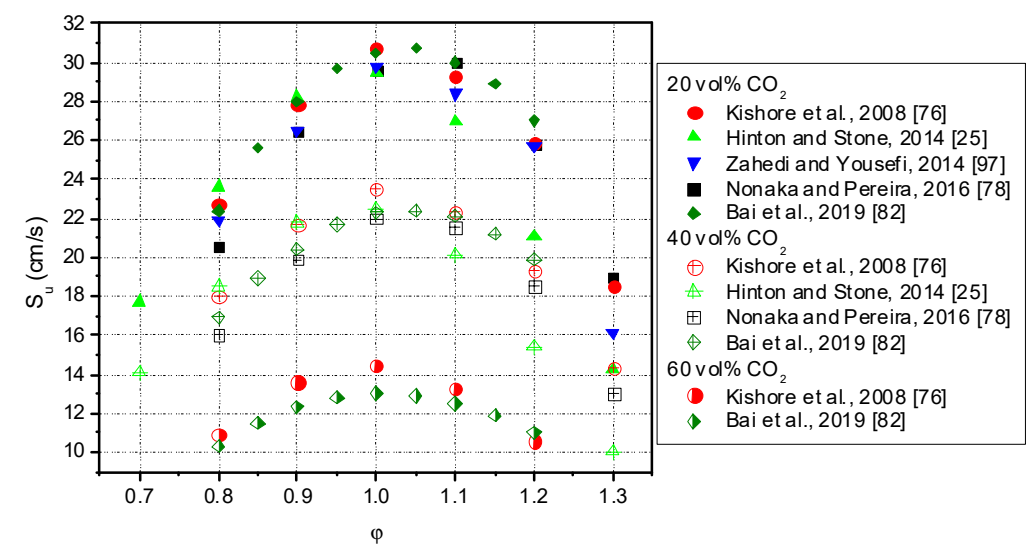

Figure 3. Variation of the experimental laminar burning velocities of biogas-air mixtures with various equivalence ratios, at different $\mathrm{CO}_{2}$ contents and standard initial conditions. 


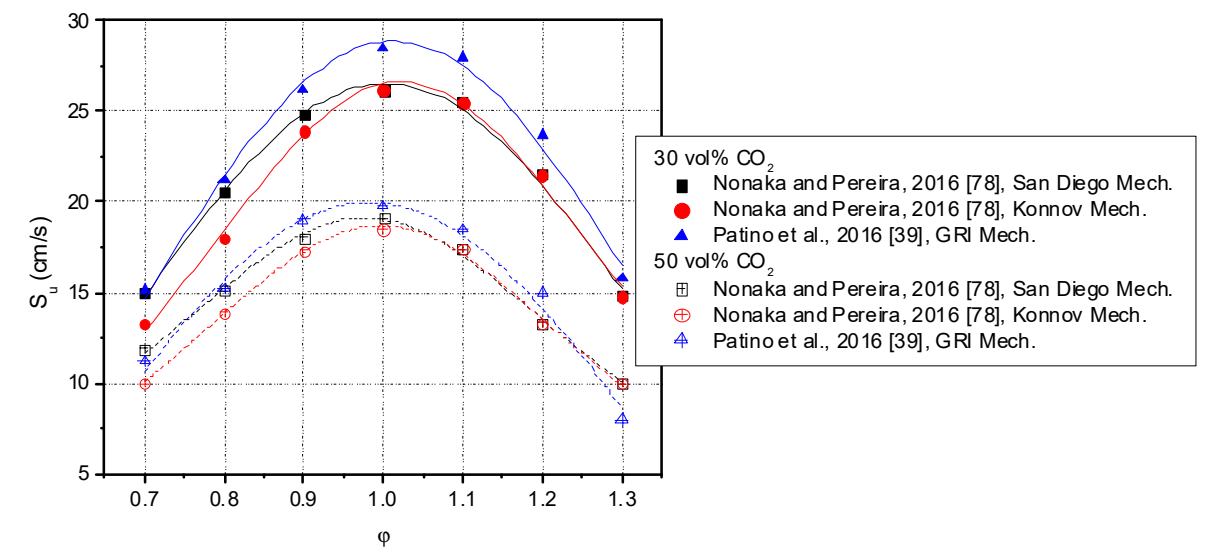

Figure 4. Variation of the calculated laminar burning velocities of biogas-air mixtures with various equivalence ratios, at different $\mathrm{CO}_{2}$ contents and standard initial conditions.

Beside the above mentioned studies that reported results from experiments and numerical modelling on the laminar burning velocity of biogas (or synthetic biogas) with a high $\mathrm{CO}_{2}$ dilution, studies were conducted with small amounts of carbon dioxide. One can mention Halter et al. [80] who conducted an experimental and numerical study to obtain the $\mathrm{CO}_{2}$ dilution effect on the laminar burning velocity of stoichiometric methane-air mixture. The experiments were made in a closed combustion vessel on stoichiometric mixtures diluted with $\mathrm{CO}_{2}$ up to $20 \%$ and ambient initial conditions. The computations were made using the CHEMKIN package with GRI-Mech 3.0 mechanism.

The influence of $\mathrm{CO}_{2}$ (10 and $20 \mathrm{vol} \%$, respectively) on the laminar burning velocity for $\mathrm{CH}_{4}$-air mixtures at various equivalence ratios (0.7-1.3), various initial pressures (1-5 bar) and initial temperature of $298 \mathrm{~K}$, was reported by Zahedi and Yousefi [97] from experiments using a flat flame burner and numerical modelling using CHEMKIN package together with the GRI-Mech 3.0 mechanism.

Chan et al. [77] realised experiments using a flat-flame burner at atmospheric pressure and $298 \mathrm{~K}$ over the methane-air equivalence ratio range of 0.8 to 1.4 and carbon dioxide content of 10 and 15\%, respectively. A kinetic modelling was also performed using CHEMKIN-PRO package with the skeletal version of Le Cong kinetic mechanisms.

Flame propagation was studied in methane-air- $\mathrm{CO}_{2}$ mixtures with various initial pressures and compositions using pressure-time records obtained in a closed vessel with central ignition [29]. The laminar burning velocities obtained from experiments were compared with those obtained from numerical modelling of 1D flame with COSILAB package and GRI-Mech 3.0 kinetic mechanism.

Regardless of the amount of carbon dioxide contained in the biogas, all authors noted that the presence of carbon dioxide in the biogas flames decreases the laminar burning velocity. This can also be observed from Figure 5 where data referring to experimental laminar burning velocities are plotted. In this figure, the laminar burning velocities for mixtures with equivalence ratio of 1.1 , at ambient initial conditions vs. carbon dioxide content are given. 


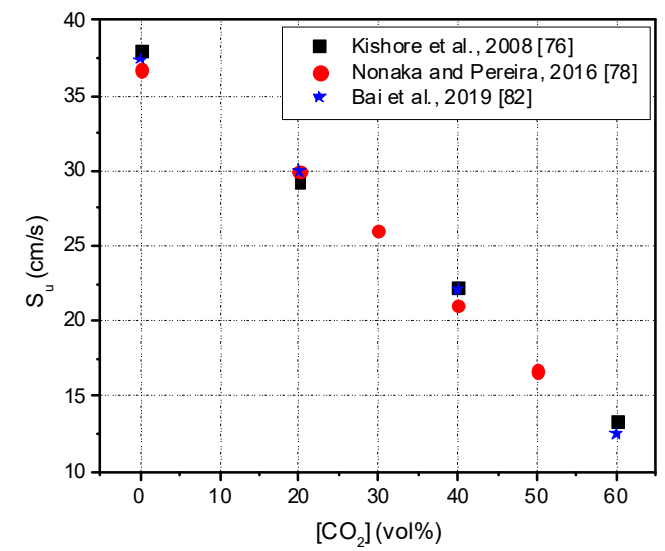

Figure 5. Variation of experimental laminar burning velocities with carbon dioxide content for $\mathrm{CH}_{4}-\mathrm{CO}_{2}$-air mixtures with equivalence ratio of 1.1 , at ambient initial conditions.

Decreasing of the laminar burning velocity with increase in carbon dioxide content is also observed when examining data from numerical modeling. Figure 6 gives experimental and numerical data from Yadav et al. [24] and the calculated data from Boushaki et al. [99].

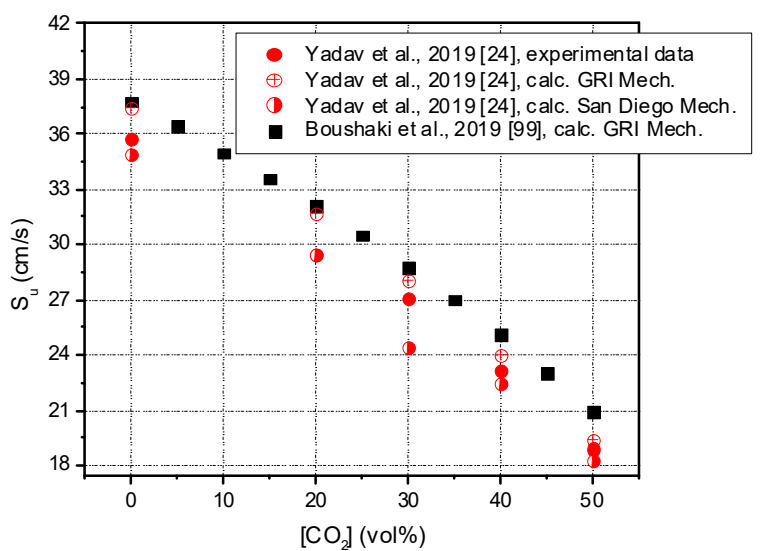

Figure 6. Variation of experimental and calculated laminar burning velocities with carbon dioxide content for mixtures with stoichiometric equivalence ratio, at standard initial conditions.

The decrease of the laminar burning velocity with the increase of $\mathrm{CO}_{2}$ content occurs due to three effects: the dilution effect, the thermal-diffusion effect and the chemical effect. By adding carbon dioxide to a mixture, the fuel and oxidant content in the mixture are reduced, decreasing the available amount of released heat and the reaction rate. The high $\mathrm{CO}_{2}$ heat capacity reduces also the adiabatic flame temperature and, hence, the reaction rates, as mentioned by Kishore et al. [76].

The decrease in the adiabatic flame temperature with $\mathrm{CO}_{2}$ content increase is observed from Figure 7 where data reported by Boushaky et al. [99] with COSILAB code and Ren et al. [41] with CHEMKIN II package for stoichiometric biogas-air mixture at $298 \mathrm{~K}$ and 1 bar are given. Xie et al. [81] noted that the flame temperature does not decrease linearly with the increase of the $\mathrm{CO}_{2}$ content. For a mixture with a higher $\mathrm{CO}_{2}$ content, the carbon dioxide has a stronger thermal effect. Meanwhile, the mixtures at lean or rich ratios show a stronger thermal effect than that at stoichiometric ratio. 


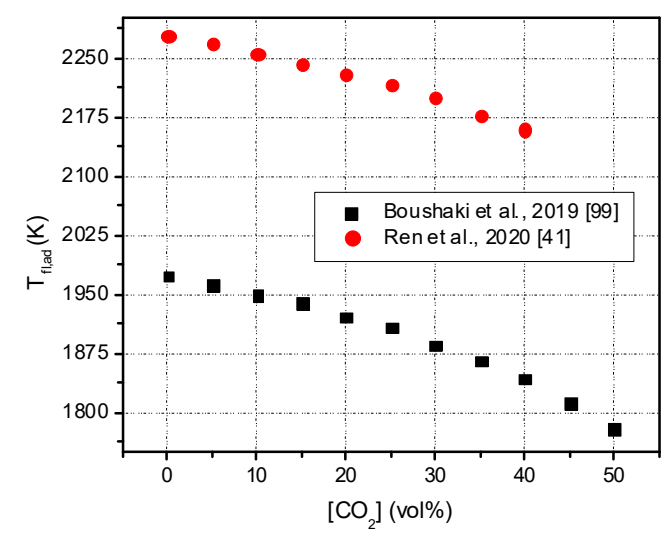

Figure 7. Adiabatic flame temperature variation with $\mathrm{CO}_{2}$ content for the stoichiometric biogas-air mixture, at $298 \mathrm{~K}$ and 1 bar.

In addition to a decrease of flame temperature, a decrease in $\mathrm{NO}_{x}$ emissions by increasing $\mathrm{CO}_{2}$ content in the biogas mixtures was observed [99]. This observation can be beneficial to reduce the $\mathrm{NO}_{\mathrm{x}}$ emissions provided by the internal combustion engines by redirecting a part of the exhaust gases into the intake manifold, lowering the combustion temperature and hence decrease of $\mathrm{NO}_{\mathrm{x}}$ emissions.

As mentioned by Ren et al. [41], $\mathrm{CO}_{2}$ is involved in the reaction $\mathrm{CO}_{2}+\mathrm{H} \Leftrightarrow \mathrm{CO}+\mathrm{OH}$. This reaction is competing for $\mathrm{H}$ atoms in reactions $\mathrm{H}+\mathrm{O}_{2} \Leftrightarrow \mathrm{OH}+\mathrm{OH}$ and $\mathrm{H}+\mathrm{O}_{2} \Leftrightarrow$ $\mathrm{O}+\mathrm{OH}$, which increase the $\mathrm{OH} / \mathrm{H}$ ratio. The increase of $\mathrm{OH} / \mathrm{H}$ ratio affects the propagation of the reaction chain and reduces the overall combustion reaction rate, and thus, the laminar burning velocity. The decrease of this parameter is more pronounced at rich mixtures (equivalence ratios $>1.0$ ). The presence of $\mathrm{CO}_{2}$ in biogas mixtures reduces the laminar burning velocity due to its physical and chemical effects. The authors mentioned that the physical effects were higher than the chemical effects. Additionally, under the flame condition, $\mathrm{CO}_{2}$ can dissociate leading to an increase in its inerting effect. Thus, examination of the total mass fraction of $\mathrm{H}$ and $\mathrm{OH}$ radicals, which are the main chain carriers and influence most significantly the fuel consumption reaction, gives us information regarding the influence of $\mathrm{CO}_{2}$ dissociation on flame propagation, as Movileanu et al. pointed out [109]. Halter et al. [80] concluded that the dissociation of $\mathrm{CO}_{2}$ is not negligible, but the effect of its dissociation is less important compared with additive amount increase. This is due to the fact that the flame temperature is lower and does not support an extensive dissociation.

Beside the carbon dioxide content influence on laminar burning velocity, the initial pressure affects also this combustion parameter. At constant equivalence ratio, carbon dioxide content and initial temperature, the laminar burning velocity decreases with the initial pressure increase as we can observe from Figure 8, where experimental and computed data delivered by Park et al. [79] on the biogas mixture $\left(55 \% \mathrm{CH}_{4}-45 \% \mathrm{CO}_{2}\right)$ at $298 \mathrm{~K}$ and on the lean, stoichiometric, and rich mixtures are plotted. This behaviour can be attributed to the fact that the effect of $\mathrm{CO}_{2}$ addition is insignificant on the flame wrinkling parameters and flame surface density, while the pressure increase strongly influences both parameters. Another representative set of data compiled from Hinton and Stone [25] is represented in Figure 9, for stoichiometric equivalence ratio, biogas composition of $60 \% \mathrm{CH}_{4}-40 \%$ $\mathrm{CO}_{2}$ and initial temperature of $400 \mathrm{~K}$. The decrease of the laminar burning velocity with the initial pressure increase is not linear, this decrease is rather exponential. According to results of $\mathrm{Hu}$ et al. [110] on $\mathrm{H}_{2}$-air flames the decrease of laminar burning velocity with the increase of initial pressure can be understood by the suppression of overall chemical reaction due to the decrease of $\mathrm{H}$ and $\mathrm{OH}$ mole fractions in flames. Hu et al. [110] found strong correlations between the laminar burning velocity and the maximum radical concentrations of $\mathrm{H}$ and $\mathrm{OH}$ radicals in the reaction zone of premixed flames of $\mathrm{H}_{2}$-air flames and concluded that high laminar burning velocities correspond to high radical concentrations in the reaction zone. 


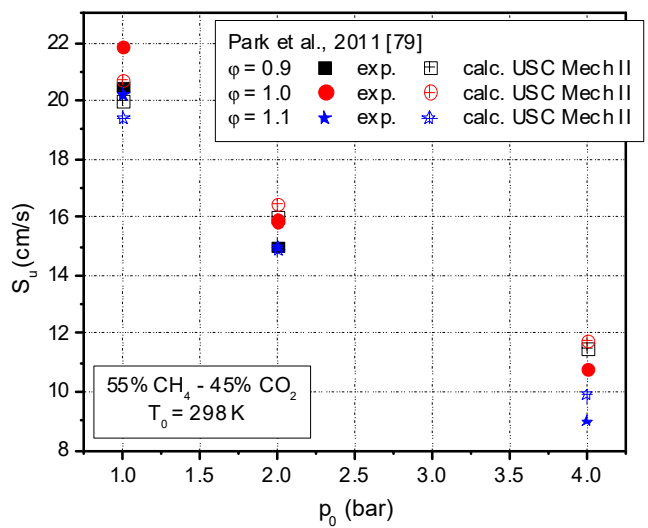

Figure 8. Initial pressure influence on laminar burning velocity, at various equivalence ratios and $298 \mathrm{~K}$.

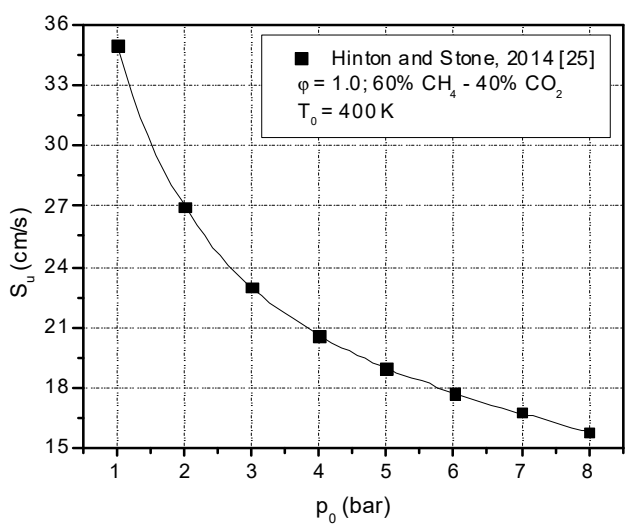

Figure 9. Initial pressure influence on experimental laminar burning velocity for stoichiometric equivalence ratio and $400 \mathrm{~K}$.

If the increase of the initial pressure decreases the laminar burning velocity, the increase of the initial temperature has an opposite effect. This behaviour is represented in Figure 10, where data from Hinton and Stone [25] for stoichiometric equivalence ratio, biogas composition of $60 \% \mathrm{CH}_{4}-40 \% \mathrm{CO}_{2}$ and initial pressure of 5 bar are given. Data from Bai et al. [82] at various equivalence ratios, ambient initial pressure and two initial temperatures are given in Figure 11. Bai et al. [82] noted that the initial temperature has a positive effect on the laminar burning velocity for all conditions, with all carbon dioxide concentration.

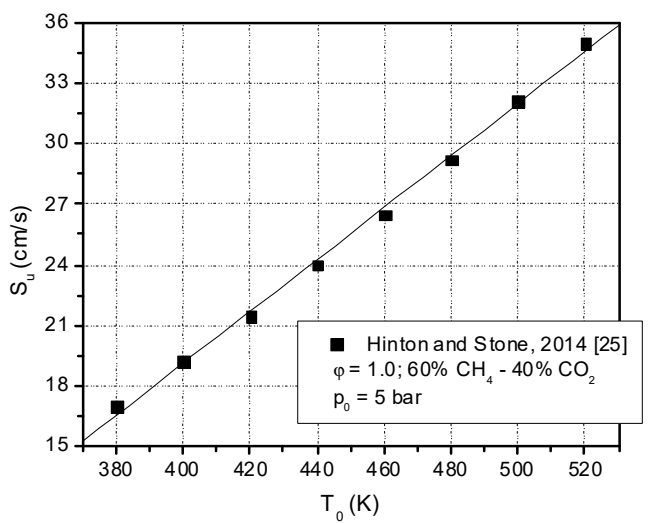

Figure 10. Initial temperature influence on experimental laminar burning velocity for stoichiometric equivalence ratio and 5 bar initial pressure. 


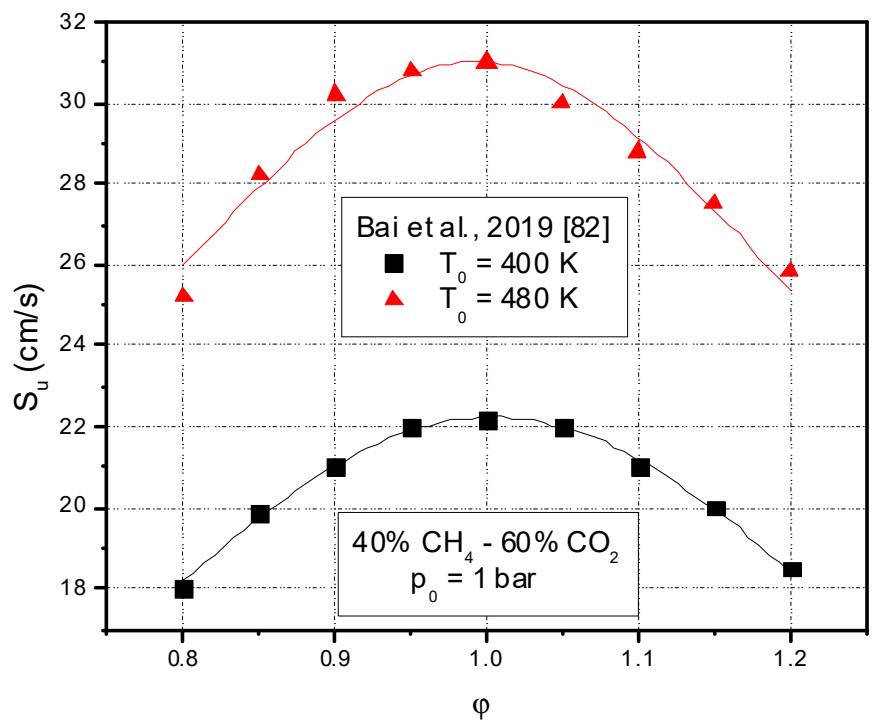

Figure 11. Initial temperature influence on experimental laminar burning velocity, at various equivalence ratios and 1 bar initial pressure.

\subsection{Effect of Hydrogen Addition on the Laminar Burning Velocity of Biogas-Air Flames}

Because the biogas has a low heating value, some studies have turned their attention to improve its relatively poor combustion characteristics. To improve the combustion properties of the biogas, it can be mixed with another combustible gas whose combustion properties, mainly the flame velocity, are greater. Given that, the hydrogen, which is a high-quality fuel with zero greenhouse potential, was chosen by some researchers to be added to biogas. The results showed a higher heat release rate, an improved stability of the flame and an increased flame temperature [42,111,112]. A significant improvement in combustion properties was observed by adding a trace amount of hydrogen into the biogas mixtures causing the acceleration of the reaction rate which counteracts the dilution effect of the large amount of $\mathrm{CO}_{2}$ from biogas [111].

The experimental and numerical methods for obtaining the laminar burning velocity of biogas- $\mathrm{H}_{2}$-air mixtures presented in this work are summarised in Table 5.

Table 5. Summary of experimental and numerical methods for obtaining the laminar burning velocity of biogas- $\mathrm{H}_{2}$-air mixtures presented in the present study.

\begin{tabular}{|c|c|c|c|}
\hline Type of Method & \multicolumn{2}{|c|}{ Method/Model/Mechanism Name } & Reference \\
\hline \multirow{3}{*}{ Experimental } & \multicolumn{2}{|c|}{ Bunsen burner } & $\begin{array}{c}\text { Acero-Caballero et al. [45] } \\
\text { Nurmukan et al. [48] } \\
\text { Zhen et al. [111] }\end{array}$ \\
\hline & \multicolumn{2}{|c|}{ Flat flame burner } & Yadav et al. [24] \\
\hline & \multicolumn{2}{|c|}{ Closed vessel } & $\begin{array}{l}\text { Suhaimi et al. [44] } \\
\text { Wei et al. [46] }\end{array}$ \\
\hline \multirow{5}{*}{ Numerical } & \multirow{3}{*}{ CHEMKIN software } & GRI-Mech 2.11 & $\begin{array}{l}\text { Acero et al. [43] } \\
\text { Acero-Caballero et al. [45] }\end{array}$ \\
\hline & & GRI-Mech. 3.0 & $\begin{array}{c}\text { Yadav et al. [24] } \\
\text { Acero-Caballero et al. [45] } \\
\text { Wei et al. [46] }\end{array}$ \\
\hline & & San Diego mechanism & $\begin{array}{l}\text { Yadav et al. [24] } \\
\text { Wei et al. [46] }\end{array}$ \\
\hline & ANSYS Fluent software & reduced GRI-Mech 3.0 & Nurmukan et al. [48] \\
\hline & Cantera package & $\begin{array}{l}\text { USC-Mech } 2.0 \\
\text { mechanism }\end{array}$ & Quintino et al. [49] \\
\hline
\end{tabular}


Zhen et al. [106] measured the laminar burning velocities of biogas- $\mathrm{H}_{2}$-air mixtures (biogas compositions $60 \% \mathrm{CH}_{4}-40 \% \mathrm{CO}_{2}$; equivalence ratios from 0.8 to 1.2) using a Bunsen burner. The $\mathrm{H}_{2}$ content varied from 10 to $50 \%$. The authors determined that there was a corresponding increase in the biogas burning rate with $\mathrm{H}_{2}$ percentage increase. For the stoichiometric biogas- $\mathrm{H}_{2}$-air mixture the laminar burning velocity increases from $25 \mathrm{~cm} / \mathrm{s}$ for $20 \% \mathrm{H}_{2}$, to $37 \mathrm{~cm} / \mathrm{s}$ for $50 \% \mathrm{H}_{2}$. For rich (equivalence ratio 1.2) biogas- $\mathrm{H}_{2}$-air mixture, the laminar burning velocity increases from $19 \mathrm{~cm} / \mathrm{s}$ for $10 \% \mathrm{H}_{2}$, to $47 \mathrm{~cm} / \mathrm{s}$ for $50 \% \mathrm{H}_{2}$. For lean (equivalence ratio 0.8 ) biogas- $\mathrm{H}_{2}$-air mixture, the flame is stable only at $50 \% \mathrm{H}_{2}$, and thus the corresponding laminar burning velocity is $25 \mathrm{~cm} / \mathrm{s}$.

Another study [43] was conducted to find the effect of hydrogen addition to biogas $\left(60 \% \mathrm{CH}_{4}-40 \% \mathrm{CO}_{2}\right)$ on the laminar burning velocity using the CHEMKIN software and GRI-Mech 2.11 mechanism. The runs were performed under normal conditions using different aeration factors. The $\mathrm{H}_{2}$ content from mixtures was $5 \%$ and $15 \%$, respectively. The results showed that the hydrogen addition to the biogas generates an acceleration of the combustion reaction and an increasing of the laminar burning velocity. For stoichiometric mixture (aeration factor of 1), the laminar burning velocity increase from $27.4 \mathrm{~cm} / \mathrm{s}$ for pure biogas, to $28.5 \mathrm{~cm} / \mathrm{s}$ for biogas with $5 \% \mathrm{H}_{2}$ and to $32.2 \mathrm{~cm} / \mathrm{s}$ for biogas with $15 \% \mathrm{H}_{2}$. For the lean mixtures (aeration factor of 1.4), the effect of hydrogen addition on the laminar burning velocity leads to a small increase, from $15.8 \mathrm{~cm} / \mathrm{s}$ for pure biogas, to $18.4 \mathrm{~cm} / \mathrm{s}$ for biogas with $15 \% \mathrm{H}_{2}$. The authors concluded that a significant improvement on the laminar burning velocity of biogas requires a hydrogen addition near $15 \%$ or more in volume.

Suhaimi et al. [44] reported the laminar burning velocities of hydrogen enriched biogas-air mixtures (biogas composition $50 \% \mathrm{CH}_{4}-50 \% \mathrm{CO}_{2}$ ) with an equivalence ratio from 0.4 to 0.9 using a constant volume combustion chamber, at initial pressure of 1 bar and temperature range of $25^{\circ} \mathrm{C}$ to $29^{\circ} \mathrm{C}$. They found that the $\mathrm{H}_{2}$ enrichment increases the biogas burning rate to a significant extent, especially at 30-40\% enrichment, while for smaller enrichment (i.e., 10-20\%) an insignificant increase in the burning rate is observed. Suhaimi et al. [44] pointed out that the maximum value of the laminar burning velocity occurs at equivalence ratio of 0.8 for all mixtures regardless of the hydrogen enrichment percentage. At this equivalence ratio the reported laminar burning velocity increase from $22.0 \mathrm{~cm} / \mathrm{s}$ at $10 \% \mathrm{H}_{2}$ addition, to $48.0 \mathrm{~cm} / \mathrm{s}$ at $40 \% \mathrm{H}_{2}$ addition.

The laminar burning velocities of biogas- $\mathrm{H}_{2}$ mixtures $\left(5 \%\right.$ or $15 \% \mathrm{H}_{2}$ by volume) were measured by using the method of the inner cone of combustion zone, under normal conditions and various aeration factors (1.0-1.4) [45]. Additionally, computational results on a biogas mixture with $60 \% \mathrm{CH}_{4}$ and $40 \% \mathrm{CO}_{2}$ obtained using CHEMKIN software and two kinetic mechanisms (GRI-Mech 2.11 and GRI-Mech 3.0) were reported. They found that the maximum value of the laminar burning velocity for biogas $-\mathrm{H}_{2}$ mixtures is reached in the stoichiometric flames, with experimental values ranging from $27.7 \mathrm{~cm} / \mathrm{s}$ for pure biogas and $29.9 \mathrm{~cm} / \mathrm{s}$ for biogas with $5 \% \mathrm{H}_{2}$. The authors noted that for biogas mixture with $15 \% \mathrm{H}_{2}$, it was not possible to obtain the deflagration rate in stoichiometric flame due to the flame instability. For aeration factors of 1.1, the values obtained were $26.1 \mathrm{~cm} / \mathrm{s}$, $26.7 \mathrm{~cm} / \mathrm{s}$ and $30.3 \mathrm{~cm} / \mathrm{s}$ for pure biogas, a mixture with $5 \% \mathrm{H}_{2}$ and a mixture with $15 \%$ $\mathrm{H}_{2}$, respectively. For mixtures with $15 \% \mathrm{H}_{2}$, the effect of hydrogen in the increase of the biogas flame speed is appreciated. The computed results have values that are close to the experimental ones.

An experimental investigation of the adiabatic laminar burning velocity of hydrogenenriched biogas mixtures was conducted using a flat flame burner, at 1 bar and $298 \mathrm{~K}$ [24]. The biogas compositions used in this paper are $50 \% \mathrm{CH}_{4}-50 \% \mathrm{CO}_{2}, 60 \% \mathrm{CH}_{4}-40 \% \mathrm{CO}_{2}$, $70 \% \mathrm{CH}_{4}-30 \% \mathrm{CO}_{2}$ and $80 \% \mathrm{CH}_{4}-20 \% \mathrm{CO}_{2}$, respectively. The amount of hydrogen was 20 or $40 \%$. Additionally, computations using CHEMKIN program with GRI-Mech. 3.0 and San Diego reaction mechanisms were used to obtain the laminar burning velocity of $\mathrm{H}_{2-}$ enriched biogas mixtures with different equivalence ratios (range of 0.7 to 1.4). The same substantial increase in the laminar burning velocity was observed with an increase in $\mathrm{H}_{2}$ content in the fuel, at all equivalence ratios and all studied biogas compositions. For exam- 
ple, for the mixtures with $60 \% \mathrm{CH}_{4}-40 \% \mathrm{CO}_{2}$ and stoichiometric ratio, the experimental laminar burning velocity increases from $19.5 \mathrm{~cm} / \mathrm{s}$ for $0 \% \mathrm{H}_{2}$, to $26.5 \mathrm{~cm} / \mathrm{s}$ for $20 \% \mathrm{H}_{2}$ and to $40.0 \mathrm{~cm} / \mathrm{s}$ for $40 \% \mathrm{H}_{2}$. The predictions of GRI Mech. 3.0 were in better agreement with the experimental values compared to other mechanism used in this work.

Wei et al. [46] conducted a study on the laminar burning velocities of biogas-hydrogenair mixture at different fuel compositions $\left(60 \% \mathrm{CH}_{4}-40 \% \mathrm{CO}_{2}, 50 \% \mathrm{CH}_{4}-50 \% \mathrm{CO}_{2}, 40 \%\right.$ $\mathrm{CH}_{4}-60 \% \mathrm{CO}_{2}$ ) and equivalence ratios (0.9-1.3) using the closed vessel method. During the experiments the initial pressure and temperature were set at 1 bar and $298 \mathrm{~K}$, respectively. The amount of hydrogen was varied between 0 and $50 \%$. In addition, simulations of the laminar burning velocity were conducted using the CHEMKIN code and GRI Mech. 3.0 and San Diego reaction mechanisms. On the whole, the GRI 3.0 mechanism had a better accuracy on predicting the laminar burning velocity of biogas-hydrogen mixture. It is obvious that the laminar burning velocity is enhanced with the increase in hydrogen fraction and the methane proportion. For the most studied mixture in literature with stoichiometric equivalence ratio $\left(60 \% \mathrm{CH}_{4}-40 \% \mathrm{CO}_{2}\right)$, the experimental results of the laminar burning velocity increase from $22.5 \mathrm{~cm} / \mathrm{s}$ for $0 \% \mathrm{H}_{2}$, to $38.8 \mathrm{~cm} / \mathrm{s}$ for $50 \% \mathrm{H}_{2}$.

The biogas mixtures $\left(60 \% \mathrm{CH}_{4}-40 \% \mathrm{CO}_{2}\right)$ enriched with $\mathrm{H}_{2}$ (0 to $40 \%$ by volume) were experimentally examined using the Bunsen burner method, over a wide range of equivalence ratios (0.8-1.3), at atmospheric pressure and $298 \pm 1 \mathrm{~K}$ [48]. The experimental values were compared with computational results obtained over various equivalence ratios using the ANSYS Fluent with reduced GRI-Mech 3.0 chemical mechanism. The obtained computed values were similar to experimental ones. The laminar burning velocities of biogas-air flames increase with the $\mathrm{H}_{2}$ enrichment of the mixture. For lean mixtures (equivalence ratio of 0.8 ), the experimental laminar burning velocities increase from $16.3 \mathrm{~cm} / \mathrm{s}$ for $0 \% \mathrm{H}_{2}$, to $30.0 \mathrm{~cm} / \mathrm{s}$ for $40 \% \mathrm{H}_{2}$. For stoichiometric mixtures, the experimental laminar burning velocities increase from $22.5 \mathrm{~cm} / \mathrm{s}$ for $0 \% \mathrm{H}_{2}$ to $43.0 \mathrm{~cm} / \mathrm{s}$ for $40 \% \mathrm{H}_{2}$. For rich mixtures (equivalence ratio of 1.2), the experimental laminar burning velocities increase from $21.0 \mathrm{~cm} / \mathrm{s}$ for $10 \% \mathrm{H}_{2}$, to $39.5 \mathrm{~cm} / \mathrm{s}$ for $40 \% \mathrm{H}_{2}$. The authors concluded that improvements in burning velocities are more pronounced in the stoichiometric and rich fuels compared with lean mixtures.

A recent paper [49] numerically investigated the laminar burning velocity of three biogas blends $\left(100 \% \mathrm{CH}_{4}, 90 \% \mathrm{CH}_{4}-10 \% \mathrm{CO}_{2}, 80 \% \mathrm{CH}_{4}-20 \% \mathrm{CO}_{2}\right)$ with hydrogen addition up to $50 \%$ in volume by Cantera package with USC-Mech 2.0 mechanism. The runs were performed at equivalence ratios between 0.8 and 1.0, initial pressure of 1 bar and initial temperature of $298 \mathrm{~K}$. Naturally, in all three cases, an increase in hydrogen content produced an increase in laminar burning velocity. For the stoichiometric mixture containing $80 \%$ $\mathrm{CH}_{4}$, the laminar burning velocity increase from $31.0 \mathrm{~cm} / \mathrm{s}$ for $0 \% \mathrm{H}_{2}$, to $52.5 \mathrm{~cm} / \mathrm{s}$ for $50 \% \mathrm{H}_{2}$.

Figure 12 compares results of the laminar burning velocities for biogas mixtures enriched with hydrogen from experiments at standard conditions and various equivalence ratios. The biogas referred to in Figure 12 consists of $60 \% \mathrm{CH}_{4}$ and $40 \% \mathrm{CO}_{2}$ and the hydrogen concentration is 20 and $40 \mathrm{vol} \%$, respectively. The results of Yadav et al. [24], Wei et al. [46] and Nurmukan et al. [48] are in closer agreement for mixtures without hydrogen and with $20 \% \mathrm{H}_{2}$. For $\mathrm{H}_{2}$-enriched mixtures with higher hydrogen content (e.g., $40 \% \mathrm{H}_{2}$ ) the values reported by Yadav et al. [24] and Nurmukan et al. [48] are in better agreement than the data from Wei et al. [46].

Another representative set of data is given in Figure 13 were data referring to a biogas with the composition of $50 \% \mathrm{CH}_{4}$ and $50 \% \mathrm{CO}_{2}$ enriched with hydrogen $(20$ and $40 \mathrm{vol} \%$ ) from experiments and modelling, at different equivalence ratio and ambient initial conditions are plotted. 


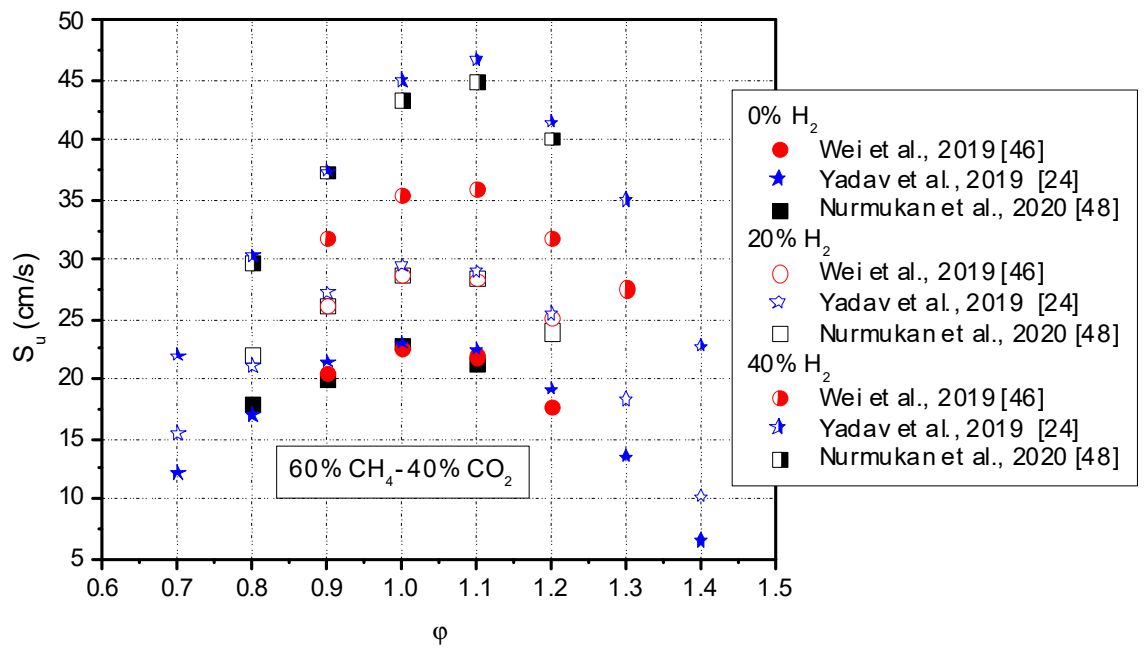

Figure 12. Variation of the experimental laminar burning velocities of $\mathrm{H}_{2}$-enriched biogas mixtures at various equivalence ratios and standard initial conditions; Biogas composition: $60 \% \mathrm{CH}_{4}-40 \% \mathrm{CO}_{2}$.
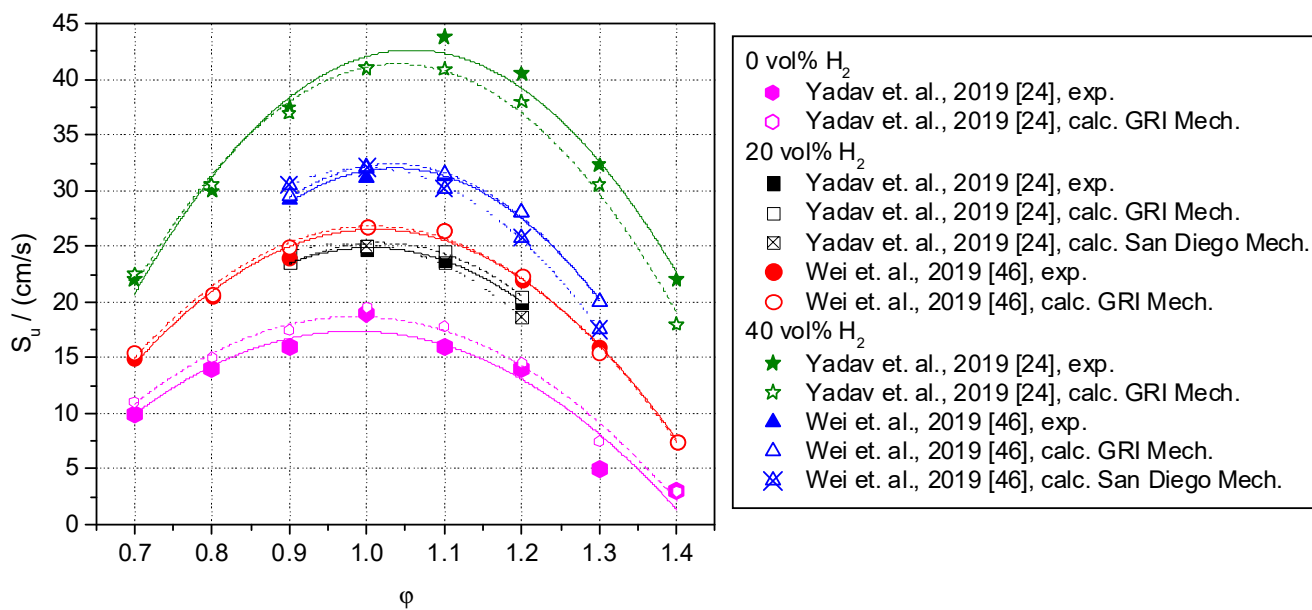

Figure 13. Variation of the laminar burning velocities of $\mathrm{H}_{2}$-enriched biogas mixtures at various equivalence ratios and standard initial conditions; Biogas composition: $50 \% \mathrm{CH}_{4}-50 \% \mathrm{CO}_{2}$.

From Figures 12 and 13 is observed that the laminar burning velocities increase with an increase in hydrogen content. The effect of hydrogen on the biogas blends is more visible from data presented in Figure 14 where a comparison of some of the experimental and numerical results obtained in the above mentioned studies regarding the one of the most common studied compositions of biogas $\left(60 \% \mathrm{CH}_{4}-40 \% \mathrm{CO}_{2}\right)$ is given. The results refer to the stoichiometric mixture, at standard conditions and various hydrogen contents. The increase in the laminar burning velocity is monotonous and is similar to the case of methane-air flames enriched with fractions of hydrogen. However, the laminar burning velocity of hydrogen-enriched biogas mixtures is higher than laminar burning velocity of methane. This is due to the fact that the laminar burning velocity of hydrogen is higher than that of methane $[113,114]$. The increase of the laminar burning velocity with increase of $\mathrm{H}_{2}$ content was also observed by Xie et al. [115] who reported data on $\mathrm{CO} / \mathrm{H}_{2} /$ air $/ \mathrm{H}_{2} \mathrm{O}$ mixtures with hydrogen content between $5 \%$ and $50 \%$. However, the authors observed that the laminar burning velocities of $\mathrm{CO} / \mathrm{H}_{2} /$ air $/ \mathrm{H}_{2} \mathrm{O}$ mixtures decrease with the increase of water content, at all studied equivalence ratios. 


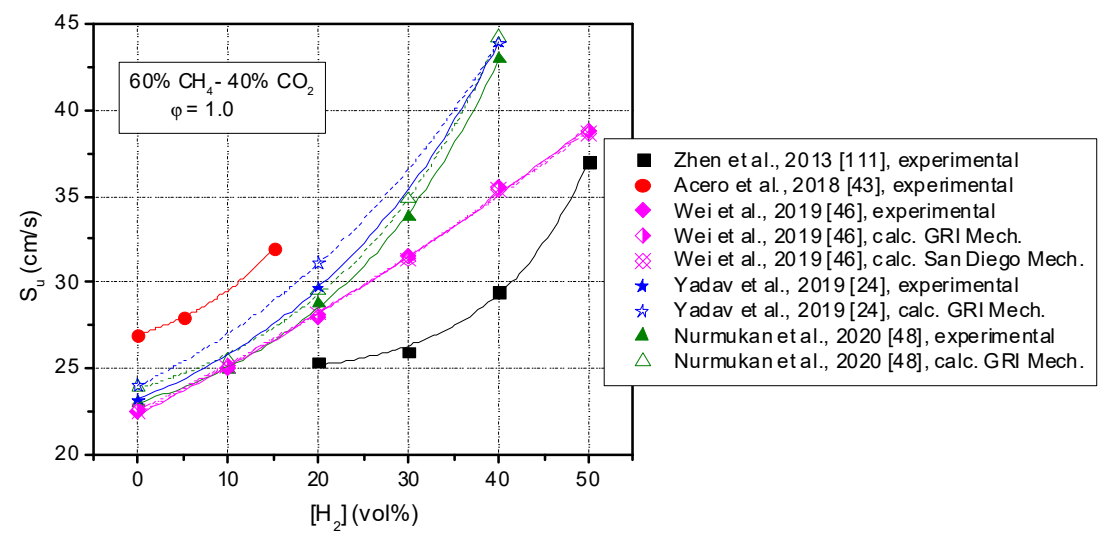

Figure 14. Comparison of the experimental and numerical results referring to the stoichiometric mixture, at standard initial conditions and various hydrogen content.

Even if the carbon dioxide concentration is high, the presence of hydrogen causes an increase in the laminar burning velocity by mitigating the thermal diffusivity and concentration effects of $\mathrm{CO}_{2}$ on the laminar burning velocity. This can be seen in Figure 15 where data regarding the biogas mixtures enriched with $40 \mathrm{vol} \% \mathrm{H}_{2}$, at equivalence ratio of 1.2, different content of carbon dioxide and standard conditions are plotted. Figure 15 shows that literature data are scattered even if both concentrations of hydrogen and carbon dioxide are maintained constant (each of them $40 \mathrm{vol} \%$ ). This is probably due to different experimental techniques: flat flame burner in the case of Yadav et al. [24]; closed vessel in the case of Wei et al. [46]; Bunsen burner in the case of Nurmukan et al. [48]. Different kinetic mechanisms also led to different results: GRI Mech. 3.0 used by Yadav et al. [24] and Wei et al. [46]; San Diego used by Wei et al. [46]; reduced GRI used by Nurmukan et al. [48].

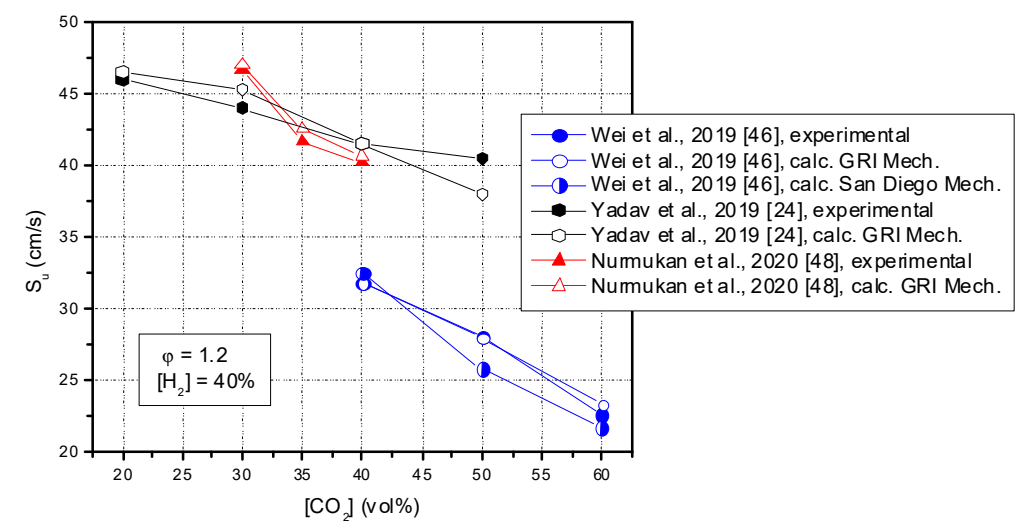

Figure 15. Influence of $\mathrm{CO}_{2}$ concentration on the laminar burning velocities of biogas mixtures with equivalence ratio of 1.2 enriched with $40 \mathrm{vol}_{\%} \mathrm{H}_{2}$, at standard initial conditions.

Despite the fact that different values of laminar burning velocities were obtained from measurements or modelling, for practical applications, large quantities of $\mathrm{H}_{2}$ added to biogas may avoid the need to completely remove of the carbon dioxide from the biogas blends. Removal of $\mathrm{CO}_{2}$ is necessary in order to increase the laminar burning velocity and the calorific value of the biogas. $\mathrm{CO}_{2}$ removal methodologies use separation by membranes, adsorption or absorption. This process involves laborious, costly, and time-consuming work, therefore $\mathrm{CO}_{2}$ removal can be replaced by the addition of hydrogen especially in some internal combustion engines which use biogas as fuel. Studies on combustion of hydrogen enriched methane and biogas were conducted in internal combustion engines [51,116,117]. The studies pointed out that, at constant initial temperature, hydrogen promotes ignition, which then occurs earlier, as a consequence of higher chemical reactivity. At constant initial pressure, hydrogen presence shifts the operating range towards lower initial gas 
temperature and lower equivalence ratio and reduces $\mathrm{NO}_{\mathrm{x}}$ emissions. The addition of hydrogen to biogas also improves combustion stability, reducing cycle-by-cycle variations. Additionally, hydrogen improves the thermal efficiency and increases the heat release rate.

The laminar burning velocity depends on the reaction rate, the thermal diffusivity and flame temperature [67]. Thus, adding hydrogen to the biogas mixture impacts the laminar burning velocity by changing the mixture properties such as the thermal diffusivity and the specific heat capacity of the mixture. Hydrogen enrichment increases the thermal diffusivity and the reaction rate, as well as the flame temperature, therefore leads to laminar burning velocity increase. Rocha et al. [118] studied the relative impact of temperature, species concentration and chemical/kinetics effects on chemiluminescence due to hydrogen enrichment in biogas-air flames using both, numerical and experiments. The authors evaluated this impact and concluded that the chemistry effect is the dominant factor in chemiluminescence. Alternatively, the kinetic or chemical effects occur because of the participation of those species containing hydrogen to the chemical reactions or pathways, while the concentration effects result from a reduced amount of a certain species, caused by an increase of another [49]. On the other hand, Fu et al. [119] observed that the flame structure of syngas mixtures with various equivalence ratio (0.5-1.8) is affected by the increase of $\mathrm{H}_{2}$ content. The authors mentioned that the flame structure is affected by both curvature effect and preferential diffusion of the fuel.

\subsection{Effect of Oxygen Addition on the Laminar Burning Velocity of Biogas-Air Flames}

Another way to improve the combustion properties of biogas is the oxygen addition to the mixture. This increases the reactivity of the mixture and therefore the laminar burning velocity. Nowadays, the oxy-fuel combustion is also considered as a promising approach for $\mathrm{CO}_{2}$ emission, thus reducing greenhouse gas emissions. This procedure consists in replacement of air in traditional combustion with pure $\mathrm{O}_{2}$ mixed with recycled flue gas (mainly containing $\mathrm{CO}_{2}$ and $\mathrm{H}_{2} \mathrm{O}$ ) for material safety and temperature control. The use of pure oxygen solves the problem of the $\mathrm{NO}_{x}$ emissions during the combustion process. $\mathrm{NO}_{x}$ emission can be reduced by removal of nitrogen from flue gases or removal of nitrogen from air before combustion. In oxy-fuel combustion, the nitrogen from air is missing, pure oxygen being used as oxidizer and therefore there are less $\mathrm{NO}_{\mathrm{x}}$ emissions from biogas combustion [120]. Additionally, the carbon dioxide concentration in the exhaust gas is high, and thus, carbon capture and storage technology are needed. As Xie et al. [81] wrote, the carbon capture and storage involves a series of processes for safe storage of $\mathrm{CO}_{2}$ emissions from fossil fuel combustion into geological storage, rather than to be released into the atmosphere. Therefore, the oxy-fuel combustion is one of the most promising technologies for carbon capture and storage. Along with carbon capture and storage technology, biogas oxy-combustion can achieve zero emissions, including $\mathrm{CO}_{2}$ [81]. Thus, some researchers conducted studies on oxy-biogas flames for a better understanding of its behaviour, in order to apply it to industrial facilities. The experimental and numerical methods for obtaining the laminar burning velocity of biogas- $\mathrm{O}_{2}$-air mixtures described in the present study are summarised in the Table 6.

For example, Cardona and Amell [56] studied numerically and experimentally the laminar burning velocity of biogas oxygen-enriched air mixtures. The experiments were made using a contoured slot burner at different air/fuel ratios, initial pressure of 0.828 bar and initial temperature of $295 \mathrm{~K}$. The biogas composition was $66 \% \mathrm{CH}_{4}-34 \% \mathrm{CO}_{2}$ and oxygen concentration was between 21 and $32 \mathrm{vol} \%$. The kinetic modelling was made using CHEMKIN-PRO package together with GRI-Mech 3.0 mechanism. The authors concluded that the addition of oxygen to the air results in more stable flames and a significant increase in the burning velocity. The experimental laminar burning velocity for stoichiometric mixtures with $21 \mathrm{vol} \% \mathrm{O}_{2}$ is $28.5 \mathrm{~cm} / \mathrm{s}$; for mixtures with $24 \mathrm{vol} \% \mathrm{O}_{2}$ is $42.5 \mathrm{~cm} / \mathrm{s}$, while for mixtures with $32 \mathrm{vol} \% \mathrm{O}_{2}$ is $58.5 \mathrm{~cm} / \mathrm{s}$. 
Table 6. Summary of experimental and numerical methods for obtaining the laminar burning velocity of biogas- $\mathrm{O}_{2}$-air mixtures described in the present study.

\begin{tabular}{|c|c|c|c|}
\hline Type of Method & Method/Mc & Mechanism Name & Reference \\
\hline \multirow{4}{*}{ Experimental } & \multicolumn{2}{|c|}{ Bunsen burner } & Hu et al. [74] \\
\hline & \multicolumn{2}{|c|}{ Contoured slot burner } & Cardona and Amell [56] \\
\hline & \multicolumn{2}{|c|}{ Flat flame burner } & Wang et al. [59] \\
\hline & \multicolumn{2}{|c|}{ Closed vessel } & Xie et al. [81] \\
\hline \multirow[t]{2}{*}{ Numerical } & \multirow[t]{2}{*}{$\begin{array}{c}\text { CHEMKIN } \\
\text { software }\end{array}$} & GRI-Mech. 3.0 & $\begin{array}{c}\text { Cardona and Amell [56] } \\
\text { Wang et al. [59] } \\
\text { Hu et al. [74] } \\
\text { Xie et al. [81] }\end{array}$ \\
\hline & & HP-Mech mechanism & Wang et al. [59] \\
\hline
\end{tabular}

Xie et al. [81] reported the laminar burning velocity of $\mathrm{CH}_{4} / \mathrm{CO}_{2} / \mathrm{O}_{2}$ mixtures from experiments and modelling at various $\mathrm{CO}_{2}$ mole fractions (0.4-0.7), equivalence ratios (0.4-1.6), initial pressures (1-3 bar) and $300 \mathrm{~K}$. The closed vessel method and CHEMKIN package (mechanism GRI-Mech 3.0) were used. The experimental results for the stoichiometric mixture and standard conditions range between $15.0 \mathrm{~cm} / \mathrm{s}$ for $\mathrm{CO}_{2}$ fraction of 0.7, to $122.0 \mathrm{~cm} / \mathrm{s}$ for $\mathrm{CO}_{2}$ fraction of 0.4 . Generally, the calculated data show a reasonable agreement with the experimental ones, especially at atmospheric pressure. However, there exists a large discrepancy when the pressure is increased. It was found that the GRI 3.0 mechanism under predicts the laminar burning velocities of $\mathrm{CH}_{4}$ oxy-fuel combustion. The discrepancy becomes larger with the decrease of the $\mathrm{CO}_{2}$ fraction.

Another study was conducted by $\mathrm{Hu}$ et al. [74] on $\mathrm{CH}_{4} / \mathrm{O}_{2} / \mathrm{CO}_{2}$ mixtures in atmospheric conditions ( $300 \mathrm{~K}$ and $1 \mathrm{bar}$ ) using a Bunsen burner. This study was performed to obtain the laminar burning velocities for a range of equivalence ratios (from 0.6 to 1.4) and oxygen concentrations (from $25 \%$ to $35 \%$ ). The experimental data were compared to numerical predictions obtained with GRI-Mech 3.0 mechanism using a CHEMKIN package. With an increase in $\mathrm{O}_{2}$ concentration, the flame speeds increased. The results showed that the maximum of the experimental laminar burning velocities appeared at the stoichiometric composition. In this case the laminar burning velocity values are as follows: $11.1 \mathrm{~cm} / \mathrm{s}$, $15.7 \mathrm{~cm} / \mathrm{s}, 20.0 \mathrm{~cm} / \mathrm{s}, 26.1 \mathrm{~cm} / \mathrm{s}, 29.6 \mathrm{~cm} / \mathrm{s}$, corresponding to $\mathrm{O}_{2}$ concentration $25 \%, 29 \%$, $31 \%, 33 \%, 35 \%$. Discrepancies between experimental and numerical data were reported, but the trend was well predicted. Later $\mathrm{Hu}$ and $\mathrm{Yu}$ [75] extended their study to elevated initial temperatures $(300 \mathrm{~K}, 400 \mathrm{~K}$ and $543 \mathrm{~K})$. The authors found that the adiabatic flame temperature increase with initial temperature increase and hence the laminar burning velocity increases. For example, the laminar burning velocities of stoichiometric mixture enriched with $30 \% \mathrm{O}_{2}$ increase from $18.2 \mathrm{~cm} / \mathrm{s}$ at $300 \mathrm{~K}$, to $49.5 \mathrm{~cm} / \mathrm{s}$ at $543 \mathrm{~K}$.

Laminar burning velocities of $\mathrm{CH}_{4} / \mathrm{O}_{2} / \mathrm{CO}_{2}$ flames were measured at elevated pressures up to $0.5 \mathrm{MPa}$ and equivalence ratios ranging from 0.6 to 1.6 using the heat flux method [59]. The oxygen molar fraction was varied from 0.31 to 0.42 . The laminar burning velocities of stoichiometric mixture obtained from measurements are $19.8 \mathrm{~cm} / \mathrm{s}, 37.0 \mathrm{~cm} / \mathrm{s}$, $48.8 \mathrm{~cm} / \mathrm{s}$, corresponding to $31 \mathrm{vol} \%, 38 \mathrm{vol} \%$ and $42 \mathrm{vol} \%$ oxygen. Kinetic modelling was also performed using the GRI-Mech 3.0 and the HP-Mech mechanisms. Data present larger discrepancies between the measured and predicted laminar burning velocities, but overall, both mechanisms predict reasonably well the laminar burning velocities.

Data from the above studies regarding the effect of oxygen enrichment on the laminar burning velocities are given in Figures 16 and 17, at various equivalence ratios and initial temperature around $300 \mathrm{~K}$. The results represented in these figures are both from experiments and modelling. As Cardona and Amell [56] noted, moderate addition of oxygen has great impact on the laminar burning velocity of pure biogas. 


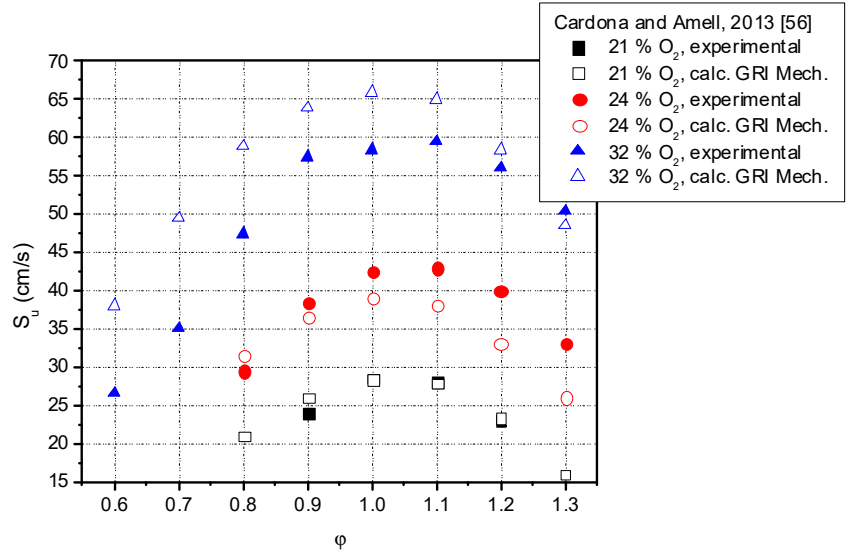

(a)

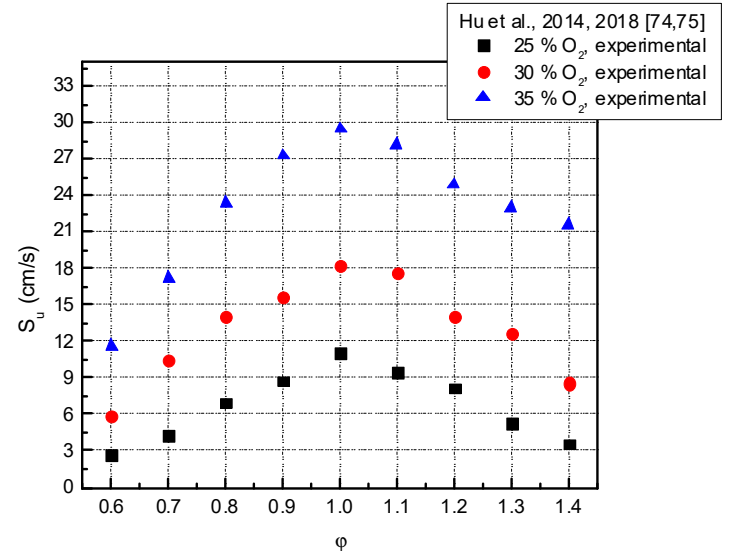

(b)

Figure 16. Laminar burning velocities of biogas mixtures enriched with oxygen. Data at: (a) 0.828 bar and $295 \mathrm{~K}$; (b) 1 bar and $300 \mathrm{~K}$.

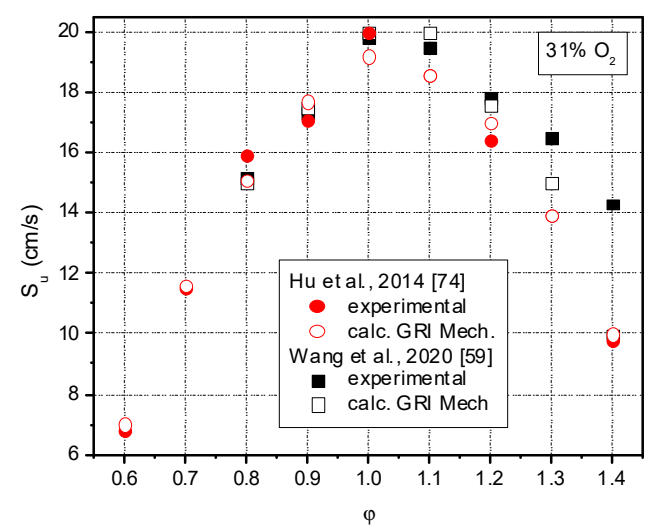

Figure 17. Laminar burning velocities of biogas mixtures enriched with oxygen at standard conditions.

The influence of oxygen addition is better seen from Figure 18 where data from experiments on lean and stoichiometric mixtures, at ambient initial conditions are plotted. $\mathrm{Hu}$ et al. [74] observed that as the oxygen concentration increases, the laminar burning velocity increase in a nonlinear relation. Experimental and modelling results indicated, through data fitting, a nearly quadratic function relationship between flame speeds and $\mathrm{O}_{2}$ concentration [74]. The authors mention that this trend is due to two reasons. First, carbon dioxide has a higher specific heat than oxygen. Thus, an increase in $\mathrm{O}_{2}$ concentration means a decrease in $\mathrm{CO}_{2}$ concentration, which raises the flame temperature to generate more radicals in chain reactions. Second, the reduction of carbon dioxide brings more chance for particle collisions, such as the [O], $[\mathrm{OH}],[\mathrm{H}]$ to cause more new chain reactions, which speed up the combustion reaction. Both reasons lead to the laminar burning velocity increase.

The increase in the amount of oxygen in the mixture results in increase of adiabatic flame temperature as it results from Figure 19, where data on stoichiometric mixture from Cardona and Amell [56], Wang et al. [59] and Hu and Yu [75] are given. The increase in the adiabatic flame temperature leads to increase in the laminar burning velocity due to the increase in mixtures' reactivity. As it results from Figures 19 and 20, the adiabatic flame temperature increases with the initial temperature increase and hence the laminar burning velocity increases. This behaviour can be also seen from Figure 21 where data collected from $\mathrm{Hu}$ and $\mathrm{Yu}[75]$ at various initial temperatures, equivalence ratios and ambient pressure are plotted. As Cardona and Amell mentioned earlier [56], these increases are partly due to the 
fact that the additional oxygen leads to a reduction of inert concentration in the unburned mixture and its consequent ability to absorb heat during the reaction, resulting in a higher flame temperature. In practical terms, the use of additional oxygen in combustion results in increased productivity in the industrial heating processes and improved flame stability.

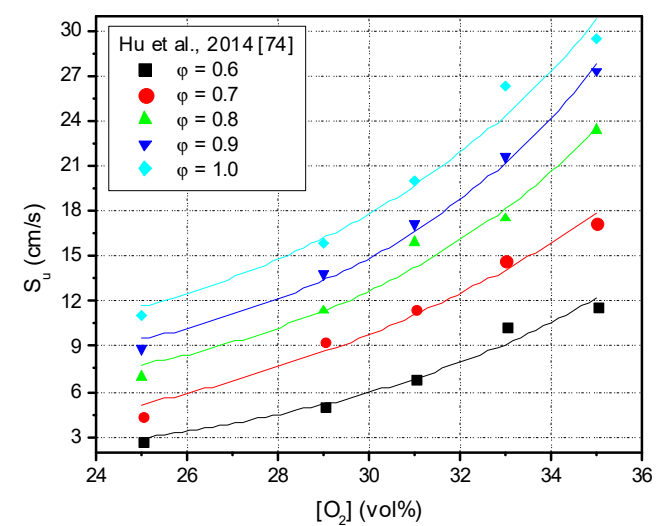

Figure 18. Influence of $\mathrm{O}_{2}$ concentration on the experimental laminar burning velocities of biogas mixtures.

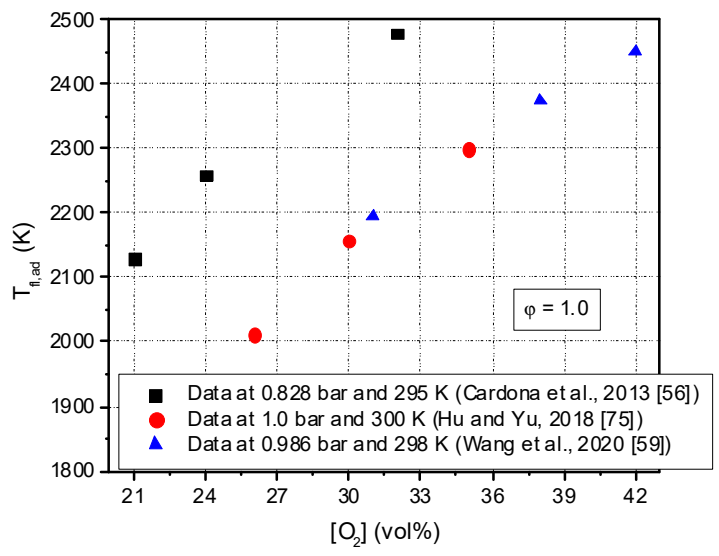

Figure 19. The adiabatic flame temperature variation with $\mathrm{O}_{2}$ content for stoichiometric biogasair mixtures.

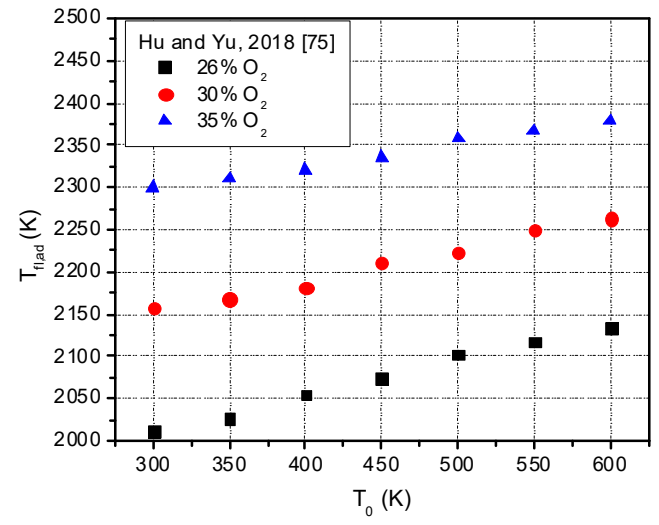

Figure 20. The adiabatic flame temperature variation with initial temperature for oxygen-enriched biogas mixtures. 


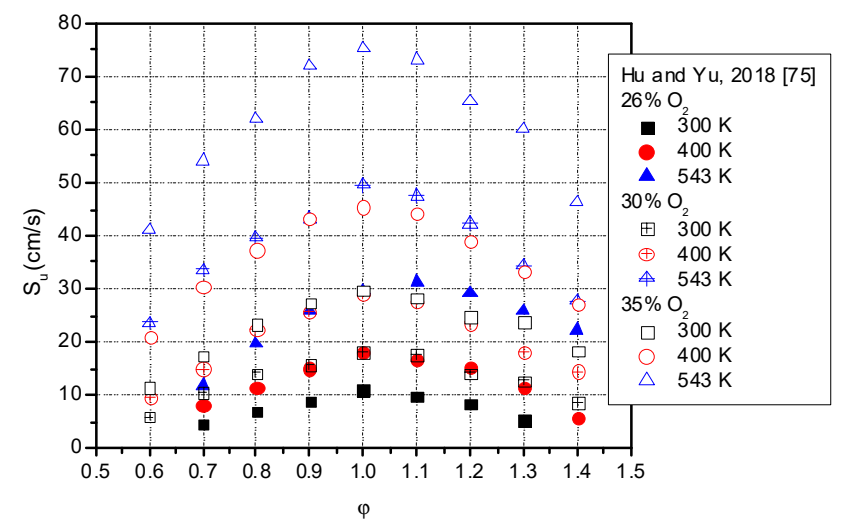

Figure 21. Influence of initial temperature on experimental laminar burning velocity of oxygenenriched biogas mixtures.

It was found that there are three ways for the initial temperature affecting the laminar burning velocity [67]. The first factor is through the reaction rate and the adiabatic flame temperature. The increase in the adiabatic flame temperatures accelerates the reaction rates. The second factor is through the transport properties of the mixtures. The increase in the adiabatic flame temperature enhances the transport effect of $\mathrm{CO}_{2}$ due to the parameters of the transport property, such as the heat conductivity, which depend on the temperature. The third factor is due to the change in density. An increase in the initial temperature increases the laminar burning velocity through the decrease in density.

Although an increase in the amount of oxygen increases laminar burning velocity, an increase in the initial pressure decreases the laminar burning velocity. This behaviour is observed from Figure 22 where experimental data on stoichiometric biogas-air-oxygen mixture, at various oxygen contents and $298 \mathrm{~K}$ are presented [59].

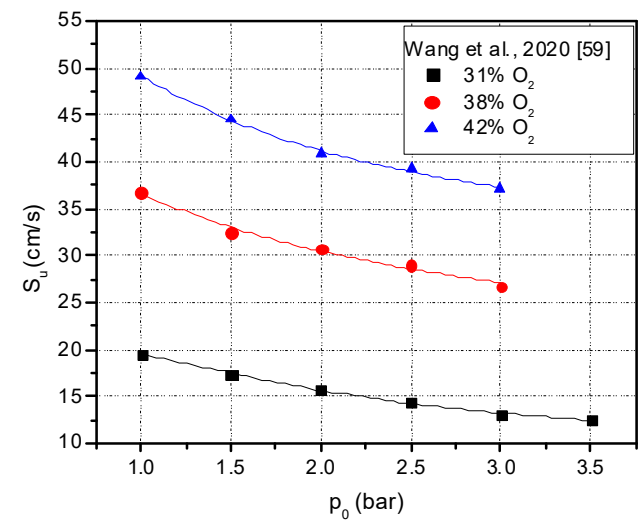

Figure 22. Initial pressure influence on experimental laminar burning velocity for stoichiometric biogas-air-oxygen mixtures. Data refers to various oxygen contents and $298 \mathrm{~K}$ initial temperature.

A small increase in the oxygen content significantly enhances the laminar burning velocities for atmospheric and elevated pressures, as well as for ambient and elevated temperatures. Therefore, the combustion properties and flame stability are significantly improved when air is enriched with pure oxygen.

\section{Conclusions}

The available literature regarding the laminar burning velocities of biogas-air mixtures has been reviewed. The results are summarized as follows:

- $\quad$ The increase in carbon dioxide content decreases laminar burning velocities no matter the initial biogas composition, pressure and temperature. This phenomenon signifi- 
cantly affects the stability of the flame, which can make it difficult to use biogas as a fuel in spark ignited engines and conventional burners.

- Addition of hydrogen to a biogas-air mixture increases the laminar burning velocity due to the increase in thermal diffusivity and the reaction rate, as well as the flame temperature of the mixture. For practical applications, large quantities of $\mathrm{H}_{2}$ added to biogas could avoid the need to completely remove of the carbon dioxide from the biogas blends.

- The addition of oxygen to biogas mixtures leads to increase of the laminar burning velocity due to the increase in the adiabatic flame temperature. Oxygen-enriched combustion of biogas can be efficient for power generation not only because of the lower $\mathrm{NO}_{\mathrm{x}}$ emissions but also because of the suitability for $\mathrm{CO}_{2}$ capture and storage. - Small quantities of hydrogen and oxygen added to biogas leads to greater flame stability and improve the combustion properties of these flames.

- The increase of the initial temperature and the decrease of the initial pressure of fuel-oxidant mixture cause the increase of both, experimental and computed laminar burning velocities.

Author Contributions: Conceptualization, V.G. and M.M.; data curation, C.M. and A.M.M.; writingoriginal draft preparation, V.G. and M.M.; visualization, V.G., C.M., A.M.M. and M.M.; formal analysis, V.G., C.M., A.M.M. and M.M. All authors have read and agreed to the published version of the manuscript.

Funding: This research received no external funding.

Institutional Review Board Statement: This statement is not applicable for our study.

Informed Consent Statement: This statement is not applicable for our study.

Data Availability Statement: This statement is not applicable for our study.

Acknowledgments: The present study was partially supported by the Romanian Academy under research project "Dynamics of fast oxidation and decomposition reactions in homogeneous systems" of Ilie Murgulescu Institute of Physical Chemistry.

Conflicts of Interest: The authors declare no conflict of interest.

\section{References}

1. Chin, M.J.; Poh, P.E.; Tey, B.T.; Chan, E.S.; Chin, K.L. Biogas from palm oil mill effluent (POME): Opportunities and challenges from Malaysia's perspective. Renew. Sust. Energ. Rev. 2013, 26, 717-726. [CrossRef]

2. Hosseini, S.E.; Wahid, M.A. Feasibility study of biogas production and utilization as a source of renewable energy in Malaysia. Renew. Sust. Energ. Rev. 2013, 19, 454-462. [CrossRef]

3. Mengistu, M.G.; Simane, B.; Eshete, G.; Workneh, T.S. A review on biogas technology and its contributions to sustainable rural livelihood in Ethiopia. Renew. Sust. Energ. Rev. 2015, 48, 306-316. [CrossRef]

4. Wang, Z.; Yelishala, S.C.; Yu, G.; Metghalchi, H.; Levendis, Y.A. Effects of carbon dioxide on laminar burning speed and flame instability of methane/air and propane/air mixtures: A literature review. Energy Fuels 2019, 33, 9403-9418. [CrossRef]

5. Sulaiman, S.Z.; Khan, N.A.M.H.; Izhab, I.; Shaarani, S.M.; Mudalip, S.K.A.; Man, R.C.; Arshad, Z.I.M.; Kasmani, R.M.; Sulaiman, S. Explosion characteristics assessment of premixed biogas/air mixture in a 20-L spherical vessel. Chem. Eng. Commun. 2021, 208, 583-591. [CrossRef]

6. Hafner, S.; Rennuit, C. Predicting Methane and Biogas Production with the Biogas Package. Biogas Software. 2015. Available online: https:/ /CRAN.R-project.org/package=biogas (accessed on 3 February 2021).

7. Coward, H.F.; Jones, G.W. Limits of flammability of gases and vapors. Bur. Mines Bull. 1952, 503. [CrossRef]

8. Schroeder, V.; Schalau, B.; Molnare, M. Explosion protection in biogas and hybrid power plants. Procedia Eng. 2014, 84, $259-272$. [CrossRef]

9. Casson Moreno, V.; Papasidero, S.; Scarponi, G.E.; Guglielmi, D.; Cozzani, V. Analysis of accidents in biogas production and upgrading. Renew. Energy 2016, 96, 1127-1134. [CrossRef]

10. Hedlund, F.H. Biomass Accident Investigations-Missed Opportunities for Learning and Accident Prevention. In Proceedings of the 25th European Biomass Conference and Exhibition, Stockholm, Sweden, 12-15 June 2017; pp. 1804-1814. [CrossRef]

11. Boscolo, M.; Bregant, L.; Miani, S.; Padoano, E.; Pille, M. An enquiry into the causes of an explosion accident occurred in a biogas plant. Process Saf. Prog. 2019, e12063. [CrossRef] 
12. Mandal, T.; Kiran, B.A.; Mandal, N.K. Determination of the quality of biogas by flame temperature measurement. Energy Convers. Manag. 1999, 40, 1225-1228. [CrossRef]

13. Forsich, C.; Lackner, M.; Winter, F.; Kopecek, H.; Wintner, E. Characterization of laser-induced ignition of biogas-air mixtures. Biomass Bioenergy 2004, 27, 299-312. [CrossRef]

14. Dupont, L.; Accorsi, A. Explosion characteristics of synthesized biogas at various temperatures. J. Hazard. Mater. 2006, 136, 520-525. [CrossRef]

15. Molnarne, M.; Schröder, V. Using explosion diagrams for estimation of the explosion limits of biogas mixtures. In Proceedings of the 2nd International Conference on Safety \& Environment in Process Industry (CISAP-2), Neaples, Italy, 21-24 May 2006.

16. Porpatham, E.; Ramesh, A.; Nagalingam, B. Effect of hydrogen addition on the performance of a biogas fuelled spark ignition engine. Intern. J. Hydrog. Energy 2007, 32, 2057-2065. [CrossRef]

17. Liu, C.; Yan, B.; Chen, G.; Bai, X.S. Structures and burning velocity of biomass derived gas flames. Intern. J. Hydrog. Energy 2010, 35, 542-555. [CrossRef]

18. Ghenai, C.; Janajreh, I. Combustion of renewable biogas fuels. J. Energy Power Eng. 2015, 9, 831-843. [CrossRef]

19. Dou, Z.; Zheng, L.; Zheng, K.; Pan, R.; Yang, W.; Fu, Y. Effect of film thickness and methane fraction on explosion characteristics of biogas/air mixture in a duct. Process Saf. Environ. Prot. 2020, 139, 26-35. [CrossRef]

20. Anggono, W.; Wardana, I.N.G.; Lawes, M.; Hughes, K.J.; Wahyudi, S.; Hamidi, N.; Hayakawa, A. Biogas laminar burning velocity and flammability characteristics in spark ignited premix combustion. J. Phys. Conf. Ser. 2013, 423, 012015. [CrossRef]

21. Anggono, W.; Wardana, I.N.G.; Lawes, M.; Hughes, K.J.; Wahyudi, S.; Hamidi, N. Laminar burning velocity and flammability characteristics of biogas in spark ignited premix combustion at reduced pressure. Appl. Mech. Mater. 2013, 376, 79-85. [CrossRef]

22. Askari, M.H.; Ashjaee, M.; Karaminejad, S. Experimental and numerical investigation of laminar burning velocity and combustion characteristics of biogas at high pressures. Energy Fuels 2017, 31, 14169-14179. [CrossRef]

23. Pizzuti, V.; Martins, C.A.; dos Santos, L.R. Experimental determination of laminar burning velocity of biogas at pressures up to 5 bar. Engenharia Térmica (Therm. Eng.) 2018, 17, 3-11. [CrossRef]

24. Yadav, V.K.; Ray, A.; Ravi, M.R. Experimental and computational investigation of the laminar burning velocity of hydrogenenriched biogas. Fuel 2019, 235, 810-821. [CrossRef]

25. Hinton, N.; Stone, R. Laminar burning velocity measurements of methane and carbon dioxide mixtures (biogas) over wide ranging temperatures and pressures. Fuel 2014, 116, 743-750. [CrossRef]

26. Anggono, W.; Hayakawa, A.; Okafor, E.C.; Gotama, G.J. Experimental and numerical investigation of laminar burning velocities of artificial biogas under various pressure and $\mathrm{CO}_{2}$ concentration. In Proceedings of the 1st International Conference on Automotive, Manufacturing, and Mechanical Engineering (IC-AMME 2018), Kuta, Indonesia, 26-28 September 2018.

27. Mitu, M.; Prodan, M.; Giurcan, V.; Razus, D.; Oancea, D. Influence of inert gas addition on propagation indices of methane-air deflagrations. Process Saf. Environ. Prot. 2016, 102, 513-522. [CrossRef]

28. Prodan, M.; Mitu, M.; Razus, D.; Oancea, D. Spark ignition and propagation properties of methane-air mixtures from early stages of pressure history. Rev. Roumaine Chim. 2016, 61, 299-307.

29. Mitu, M.; Giurcan, V.; Razus, D.; Oancea, D. Inert gas influence on laminar burning velocity of methane-air mixtures. J. Hazard. Mater. 2017, 321, 440-448. [CrossRef]

30. Mitu, M.; Giurcan, V.; Razus, D.; Prodan, M.; Oancea, D. Propagation indices of methane-air explosions in closed vessels. J. Loss Prev. Process Ind. 2017, 47, 110-119. [CrossRef]

31. Mitu, M.; Giurcan, V.; Razus, D.; Oancea, D. Inert gas influence on propagation velocity of methane-air laminar flames. Rev. Chim. 2018, 69, 196-200. [CrossRef]

32. Razus, D.; Mitu, M.; Giurcan, V.; Oancea, D. Propagation indices of methane-nitrous oxide flames in the presence of inert additives. J. Loss Prev. Process Ind. 2017, 49, 418-426. [CrossRef]

33. Razus, D.; Mitu, M.; Giurcan, V.; Oancea, D. Methane-unconventional oxidant flames. Laminar burning velocities of nitrogendiluted methane- $\mathrm{N}_{2} \mathrm{O}$ mixtures. Process Saf. Environ. Prot. 2018, 114, 240-250. [CrossRef]

34. Porpatham, E.; Ramesh, A.; Nagalingam, B. Investigation on the effect of concentration of methane in biogas when used as a fuel for a spark ignition engine. Fuel 2008, 87, 1651-1659. [CrossRef]

35. Saito, N.; Ogawa, Y.; Saso, Y.; Liao, C.; Sakei, R. Flame-extinguishing concentration and peak concentrations of $\mathrm{N}_{2}, \mathrm{Ar} \mathrm{CO}_{2}$ and their mixtures for hydrocarbon fuels. Fire Saf. J. 1996, 27, 185-200. [CrossRef]

36. Lisochkin, Y.A.; Poznyak, V.I. Inerting of methane-air mixtures by compositions based on carbon dioxide and nitrogen with addition of halocarbons. Combust. Explos. Shock Waves 2005, 41, 504-509. [CrossRef]

37. Seiser, R.; Seshadri, K. The influence of water on extinction and ignition of hydrogen and methane flames. Proc. Combus. Inst. 2005, 30, 407-414. [CrossRef]

38. Cohé, C.; Chauveau, C.; Gökalp, I.; Kurtuluş, D.F. $\mathrm{CO}_{2}$ addition and pressure effects on laminar and turbulent lean premixed $\mathrm{CH}_{4}$ air flames. Proc. Combust. Inst. 2009, 32, 1803-1810. [CrossRef]

39. Patino, M.A.M.; Alviso, D.; dos Santos, R.G. Numerical study of laminar premixed methane/air flames with carbon dioxide dilution. In Proceedings of the 16th Brazilian Congress of Thermal Sciences and Engineering, Vitória, Brazil, 7 November 2016.

40. Jithin, E.V.; Varghese, R.J.; Velamati, R.K. Experimental and numerical investigation on the effect of hydrogen addition and $\mathrm{N}_{2} / \mathrm{CO}_{2}$ dilution on laminar burning velocity of methane/oxygen mixtures. Intern. J. Hydrog. Energy 2020, 45, 16838-16850. [CrossRef] 
41. Ren, F.; Xiang, L.; Chu, H.; Jiang, H.; Ya, Y. Modeling study of the impact of blending $\mathrm{N}_{2}, \mathrm{CO}_{2}$, and $\mathrm{H}_{2} \mathrm{O}$ on characteristics of $\mathrm{CH}_{4}$ laminar premixed combustion. Energy Fuels 2020, 34, 1184-1192. [CrossRef]

42. Li, J.; Huang, H.; Osaka, Y.; Bai, Y.; Kobayashi, N.; Chen, Y. Combustion and heat release characteristics of biogas under Hydrogenand Oxygen-enriched condition. Energies 2017, 10, 1200. [CrossRef]

43. Acero, M.J.; Pacheco, L.E.; Diaz, C.A. Numerical study of the effect of hydrogen addition on the laminar flame speed and premixed flame structure of biogas. Int. J. Renew. Energy Res. 2018, 8, 1098-1104.

44. Suhaimi, M.S.; Saat, A.; Abdul Wahid, M.; Rahman, M.M.; Daierobbi, G. Effect of hydrogen addition on biogas combustion and flame propagation. J. Mek. 2018, 41, 17-23.

45. Acero-Caballero, M.J.; Pacheco-Sandoval, L.E.; Díaz-González, C.A. Effect of hydrogen addition on the laminar flame speed of biogas. Experimental and numerical study. Sci. Tech. 2019, 24, 472-478. [CrossRef]

46. Wei, Z.; Zhen, H.; Fu, J.; Leung, C.; Cheung, C.; Huang, Z. Experimental and numerical study on the laminar burning velocity of hydrogen enriched biogas mixture. Intern. J. Hydrog. Energy 2019, 44, 22240-22249. [CrossRef]

47. Zheng, L.; Dou, Z.; Du, D.; Wang, X.; Jin, H.; Yu, M.; Wang, Y. Study on explosion characteristics of premixed hydrogen/biogas/air mixture in a duct. Intern. J. Hydrog. Energy 2019, 44, 27159-27173. [CrossRef]

48. Nurmukan, D.; Chen, T.J.M.; Hung, Y.M.; Ismadi, M.Z.; Chong, C.T.; Tran, M.V. Enhancement of biogas/air combustion by hydrogen addition at elevated temperatures. Int. J. Energy Res. 2020, 44, 1519-1534. [CrossRef]

49. Quintino, F.M.; Fernandes, E.C. Numerical investigation of the impact of $\mathrm{H}_{2}$ enrichment on lean biogas/air flames: An analytical modelling approach. Energies 2021, 14, 369. [CrossRef]

50. Jeong, C.; Kim, T.; Lee, K.; Song, S.; Chung, K.M. Generating efficiency and emissions of a spark-ignition gas engine generator fuelled with biogas-hydrogen blends. Intern. J. Hydrog. Energy 2009, 34, 9620-9627. [CrossRef]

51. Rakopoulos, C.D.; Michos, C.N. Generation of combustion irreversibilities in a spark ignition engine under biogas-hydrogen mixtures fuelling. Intern. J. Hydrog. Energy 2009, 34, 4422-4437. [CrossRef]

52. Bouguessa, R.; Tarabet, L.; Loubar, K.; Belmrabet, T.; Tazerout, M. Experimental investigation on biogas enrichment with hydrogen for improving the combustion in diesel engine operating under dual fuel mode. Intern. J. Hydrog. Energy 2020, 45, 9052-9063. [CrossRef]

53. Khatri, N.; Khatri, K.K. Hydrogen enrichment on diesel engine with biogas in dual fuel mode. Int. J. Hydrog. Energy 2020, 45, 7128-7140. [CrossRef]

54. Cacua, K.; Amell, A.; Cadavid, F. Effects of oxygen enriched air on the operation and performance of a diesel-biogas dual fuel engine. Biomass Bioenergy 2012, 45, 159-167. [CrossRef]

55. Oh, J.; Noh, D. Laminar burning velocity of oxy-methane flames in atmospheric condition. Energy 2012, 45, 669-675. [CrossRef]

56. Cardona, C.A.; Amell, A.A. Laminar burning velocity and interchangeability analysis of biogas/C3H8/H2 with normal and oxygen-enriched air. Intern. J. Hydrog. Energy 2013, 38, 7994-8001. [CrossRef]

57. Navarro-Puyuelo, A.; Reyero, I.; Moral, A.; Bimbela, F.; Bañares, M.A.; Gandía, L.M. Effect of oxygen addition, reaction temperature and thermal treatments on syngas production from biogas combined reforming using Rh/alumina catalysts. J. Ind. Eng. Chem. 2019, 80, 217-226. [CrossRef]

58. Striūgas, N.; Zakarauskas, K.; Paulauskas, R.; Skvorčinskienè, R. Chemiluminescence-based characterization of tail biogas combustion stability under syngas and oxygen-enriched conditions. Exp. Therm. Fluid Sci. 2020,116, 110133. [CrossRef]

59. Wang, S.; Wang, Z.; He, Y.; Han, X.; Sun, Z.; Zhu, Y.; Costa, M. Laminar burning velocities of $\mathrm{CH}_{4} / \mathrm{O}_{2} / \mathrm{N}_{2}$ and oxygen-enriched $\mathrm{CH}_{4} / \mathrm{O}_{2} / \mathrm{CO}_{2}$ flames at elevated pressures measured using the heat flux method. Fuel 2020, 259, 116152. [CrossRef]

60. Pizzuti, L.; Martins, C.A.; Lacava, P.T. Laminar burning velocity and flammability limits in biogas: A literature review. Renew. Sustain. Energy Rev. 2016, 62, 856-865. [CrossRef]

61. Chen, Z.; Burke, M.P.; Ju, Y. Effects of Lewis number and ignition energy on the determination of laminar flame speed using propagating spherical flames. Proc. Combust. Inst. 2009, 32, 1253-1260. [CrossRef]

62. Pizzuti, L.; Torres, F.A.; Ferreira, R.W.; dos Santos, L.R.; Lacava, P.T.; Martins, C.A. Laminar Burning and Flammability Limits in Biogas: A State of the Art. In Proceedings of the 10th International Conference on Heat Transfer, Fluid Mechanics and Thermodynamics, Orlando, FL, USA, 14-16 July 2014. Available online: http://hdl.handle.net/2263/44642 (accessed on 8 February 2021).

63. Rallis, C.J.; Garforth, A.M. The determination of laminar burning velocity. Prog. Energy Combust. Sci. 1980, 6, 303-329. [CrossRef]

64. Egolfopoulos, F.N.; Hansen, N.; Ju, Y.; Kohse-Höinghaus, K.; Law, C.K.; Qi, F. Advances and challenges in laminar flame experiments and implications for combustion chemistry. Prog. Energy Combust. Sci. 2014, 43, 36-67. [CrossRef]

65. Andrews, G.E.; Bradley, D. Determination of burning velocities: A critical review. Combust Flame 1972, 18, 133-153. [CrossRef]

66. Forman, A.W. Combustion Theory, 2nd ed.; The Benjamin/Cummings Publishing Copmany: Princeton, NJ, USA, 1984.

67. Law, C.K. Combustion Physics; Cambridge University Press: New York, NY, USA, 2006.

68. Kuo, K.K. Principles of Combustion, 2nd ed.; John Wiley and Sons Inc.: Hoboken, NJ, USA, 2005.

69. Dooley, S.; Won, S.H.; Chaos, M.; Heyne, J.; Ju, Y.; Dryer, F.L.; Kumar, K.; Sung, C.J.; Wang, H.; Oehlschlaeger, M.A.; et al. A jet fuel surrogate formulated by real fuel properties. Combust. Flame 2010, 157, 2333-2339. [CrossRef]

70. Correa, S.M. A Review of NOx Formation Under gas-turbine combustion conditions. Combust. Sci. Technol. 1993, 87, 329-362. [CrossRef]

71. Flamme, M. New combustion systems for gas turbines (NGT). Appl. Therm. Eng. 2004, 24, 1551-1559. [CrossRef] 
72. Lewis, B.; von Elbe, G. Determination of the speed of flames and the temperature distribution in a spherical bomb from time-pressure explosion records. J. Chem. Phys. 1934, 2, 283-290. [CrossRef]

73. Konnov, A.A.; Mohammad, A.; Kishore, V.R.; Kim, N.I.; Prathap, C.; Kumar, S. A comprehensive review of measurements and data analysis of laminar burning velocities for various fuel + air mixtures. Prog. Energy Combust. Sci. 2018, 68, 197-267. [CrossRef]

74. $\mathrm{Hu}, \mathrm{X}$; Yu, Q.; Liu, J.; Sun, N. Investigation of laminar flame speeds of $\mathrm{CH}_{4} / \mathrm{O}_{2} / \mathrm{CO}_{2}$ mixtures at ordinary pressure and kinetic simulation. Energy 2014, 70, 626-634. [CrossRef]

75. $\mathrm{Hu}, \mathrm{X}$; $\mathrm{Yu}, \mathrm{Q}$. Effect of the elevated initial temperature on the laminar flame speeds of oxy-methane mixtures. Energy 2018, 147, 876-883. [CrossRef]

76. Kishore, V.R.; Duhan, N.; Ravi, M.R.; Ray, A. Measurement of adiabatic burning velocity in natural gas-like mixtures. Exp. Therm. Fluid Sci. 2008, 33, 10-16. [CrossRef]

77. Chan, Y.; Zhu, M.; Zhang, Z.; Liu, P.; Zhang, D. The effect of $\mathrm{CO}_{2}$ dilution on the laminar burning velocity of premixed methane/air flames. Energy Procedia 2015, 75, 3048-3053. [CrossRef]

78. Nonaka, H.O.B.; Pereira, F.M. Experimental and numerical study of $\mathrm{CO}_{2}$ content effects on the laminar burning velocity of biogas. Fuel 2016, 182, 382-390. [CrossRef]

79. Park, O.; Veloo, P.S.; Liu, N.; Egolfopoulos, F.N. Combustion characteristics of alternative gaseous fuels. Proc. Combust. Inst. 2011, 33, 887-894. [CrossRef]

80. Halter, F.; Foucher, F.; Landry, L.; Mounaïm-Rousselle, C. Effect of dilution by nitrogen and/or carbon dioxide on methane and iso-octane air flames. Combust. Sci. Technol. 2009, 181, 813-827. [CrossRef]

81. Xie, Y.; Wang, J.; Zhang, M.; Gong, J.; Jin, W.; Huang, Z. Experimental and numerical study on laminar flame characteristics of methane oxy-fuel mixtures highly diluted with $\mathrm{CO}_{2}$. Energy Fuels 2013, 27, 6231-6237. [CrossRef]

82. Bai, Z.; Wang, Z.; Yu, G.; Yang, Y.; Metghalchi, H. Experimental study of laminar burning speed for premixed biomass/air flame. J. Energy Resour. Technol. 2019, 141, 022206. [CrossRef]

83. Stone, R.; Clarke, A.; Beckwith, B. Correlations for the laminar burning velocity of methane/diluent/air mixtures obtained in free-fall experiments. Combust. Flame 1998, 114, 546-555. [CrossRef]

84. Anggono, W.; Wardana, I.N.G.; Lawes, M.; Hughes, K.J.; Wahyudi, S.; Hamidi, N.; Hayakawa, A. The influence of $\mathrm{CO}_{2}$ in biogas flammability limit and laminar burning velocity in spark ignited premix combustion at various pressures. Sustain. Energy Adv. Mater. AIP Conf. Proc. 2016, 1717, 030001-1-030001-7. [CrossRef]

85. Vagelopoulos, C.M.; Egolfopoulos, F.N. Direct experimental determination of laminar flame speeds. Symp. Int. Combust. 1998, 27, 513-519. [CrossRef]

86. Law, C.K. Dynamics of stretched flames. Symp. Int. Combust. Proc. 1989, 22, 1381-1402. [CrossRef]

87. Echekki, T.; Mungal, M.G. Flame speed measurements at the tip of a slot burner: Effects of flame curvature and hydrodynamic stretch. Symp. Int. Combust. Proc. 1991, 23, 455-461. [CrossRef]

88. Gaydon, A.G.; Wolfhard, H.G. Flames: Their Structure, Radiation, and Temperature, 3rd ed.; Chapman \& Hall Ltd.: New York, NY, USA, 1970.

89. Tsuji, H. Experimental studies of near limit flames using counterflow flame techniques. In Proceedings of the ASME-JSME Thermal Engineering Joint Conference Proceedings, Honolulu, HI, USA, 20-24 March 1983; p. 9.

90. Wu, C.K.; Law, C.K. On the determination of laminar flame speeds from stretched flames. Symp. Int. Combust. 1985, 20, 1941-1949. [CrossRef]

91. Zhu, D.L.; Egolfopoulos, F.N.; Law, C.K. Experimental and numerical determination of laminar flame speeds of methane/(Ar, $\mathrm{N}_{2}$, $\mathrm{CO}_{2}$ )-air mixtures as function of stoichiometry, pressure, and flame temperature. Symp. Int. Combust. 1989, 22, 1537-1545. [CrossRef]

92. Chen, Z.; Burke, M.P.; Ju, Y.G. Effects of compression and stretch on the determination of laminar flame speeds using propagating spherical flames. Combust. Theory Modeling 2009, 13, 343-364. [CrossRef]

93. Faghih, M.; Chen, Z. The constant-volume propagating spherical flame method for laminar flame speed measurement. Sci. Bull. 2016, 61, 1296-1310. [CrossRef]

94. Xiouris, C.; Ye, T.; Jayachandran, J.; Egolfopoulos, F.N. Laminar flame speeds under engine-relevant conditions: Uncertainty quantification and minimization in spherically expanding flame experiments. Combust Flame 2016, 163, 270-283. [CrossRef]

95. Mével, R.; Lafosse, F.; Chaumeix, N.; Dupré, G.; Paillard, C.E. Spherical expanding flames in $\mathrm{H}_{2}-\mathrm{N}_{2} \mathrm{O}-$ Ar mixtures: Flame speed measurements and kinetic modelling. Intern. J. Hydrog. Energy 2009, 34, 9007-9018. [CrossRef]

96. Razus, D.; Oancea, D.; Movileanu, C. Burning velocity evaluation from pressure evolution during the early stage of closed-vessel explosions. J. Loss Prev. Process Ind. 2006, 19, 334-342. [CrossRef]

97. Zahedi, P.; Yousefi, K. Effects of pressure and carbon dioxide, hydrogen and nitrogen concentration on laminar burning velocities and NO formation of methane-air mixtures. J. Mech. Sci. Technol. 2014, 28, 377-386. [CrossRef]

98. Goodwin, D.; Moffat, H.; Speth, R. Cantera: An Object-Oriented Software Toolkit for Chemical Kinetics, Thermodynamics, and Transport Processes. 2015. Available online: http://www.cantera.org (accessed on 19 February 2021).

99. Boushaki, T.; Zaidaoui, H.; Manseur, F.; Rahib, Y.; Sarh, B. Characteristics of Biogas and Syngas Combustion. In Proceedings of the 7th International Renewable and Sustainable Energy Conference (IRSEC), Agadir, Morocco, 27-30 November 2019. [CrossRef] 
100. Smith, G.P.; Golden, D.M.; Frenklach, M.; Moriarty, N.W.; Goldenberg, B.E.M.; Bowman, C.T.; Hanson, R.K.; Song, S.; Gardiner, W.C.; Lissianski, V.V.; et al. GRI-Mech 3.0. 1999. Available online: http:/ / combustion.berkeley.edu/gri-mech/version30/text30. html (accessed on 19 February 2021).

101. Wang, H.; You, X.; Joshi, A.V.; Davis, S.G.; Laskin, A.; Egolfopoulos, F.N.; Law, C.K. High-Temperature Combustion Reaction Model of H2/CO/C1-C4 Compounds. USC Mech, Version II; Combustion Kinetics Laboratory, University of Southern California. 2007. Available online: http://ignis.usc.edu/USC_Mech_II.htm (accessed on 10 May 2021).

102. Petrova, M.V.; Williams, F.A. A small detailed chemical kinetic mechanism for hydrocarbon combustion. Combust. Flame 2006, 144, 526-544. [CrossRef]

103. Qin, Z.; Lissianski, V.V.; Yang, H.; Gardiner, W.C.; Davis, S.G.; Wang, H. Combustion chemistry of propane: A case study of detailed reaction mechanism optimization. Proc. Combust. Inst. 2000, 28, 1663-1669. [CrossRef]

104. Le Cong, T.; Dagaut, P. Experimental and detailed kinetic modeling of the oxidation of methane and methane/syngas mixtures and effect of carbon dioxide addition. Combust. Sci. Technol. 2008, 180, 2046-2091. [CrossRef]

105. Le Cong, T.; Dagaut, P.; Dayma, G. Oxidation of natural gas, natural gas/syngas mixtures, and effect of burnt gas recirculation: Experimental and detailed kinetic modeling. J. Eng. Gas Turbine Power 2008, 130, 41502. [CrossRef]

106. Zhen, H.S.; Leung, C.W.; Cheung, C.S.; Huang, Z.H. Characterization of biogas-hydrogen premixed flames using Bunsen burner. Int. J. Hydrog. Energy 2014, 39, 13292-13299. [CrossRef]

107. Qin, W.; Egolfopoulos, F.N.; Tsotsis, T.T. Fundamental and environmental aspects of landfill gas utilization for power generation. Chem. Eng. J. 2001, 82, 157-172. [CrossRef]

108. Ju, Y.; Masuya, G.; Ronney, P.D. Effects of radiative emission and absorbtion on the propagation of premixed gas flames. Symp. Intern. Combust. 1998, 27, 2619-2626. [CrossRef]

109. Movileanu, C.; Razus, D.; Oancea, D. Additive effects on the burning velocity of ethylene-air mixtures. Energy Fuels 2011, 25, 2444-2451. [CrossRef]

110. Hu, E.; Huang, Z.; He, J.; Miao, H. Experimental and numerical study on laminar burning velocities and flame instabilities of hydrogen-air mixtures at elevated pressures and temperatures. Intern. J. Hydrog. Energy 2009, 34, 8741-8755. [CrossRef]

111. Zhen, H.; Leung, C.; Cheung, C. Effects of hydrogen addition on the characteristics of a biogas diffusion flame. Int. J. Hydrog. Energy 2013, 38, 6874-6881. [CrossRef]

112. Wei, Z.; Leung, C.; Cheung, C.; Huang, Z. Effects of equivalence ratio, $\mathrm{H}_{2}$, and $\mathrm{CO}_{2}$ addition on the heat release characteristics of premixed laminar biogas-hydrogen flame. Intern. J. Hydrog. Energy 2016, 41, 6567-6580. [CrossRef]

113. Coppens, F.H.V.; Ruyck, J.D.; Konnov, A.A. Effects of hydrogen enrichment on adiabatic burning velocity and NO formation in methane + air flames. Exp. Therm. Fluid. Sci. 2007, 31, 437-444. [CrossRef]

114. Hu, E.; Huang, Z.; He, J.; Jin, C.; Zheng, J. Experimental and numerical study on laminar burning characteristics of premixed methane-hydrogen-air flame. Intern. J. Hydrog. Energy 2009, 34, 4876-4888. [CrossRef]

115. Xie, Y.; Wang, J.; Xu, N.; Yu, S.; Zhang, M.; Huang, Z. Thermal and chemical effects of water addition on laminar burning velocity of syngas. Energy Fuels 2014, 28, 3391-3398. [CrossRef]

116. Park, C.; Park, S.; Lee, Y.; Kim, C.; Lee, S.; Moriyoshi, Y. Performance and emission characteristics of a SI engine fueled by low calorific biogas blended with hydrogen. Int. J. Hydrog. Energy 2011, 36, 10080-10088. [CrossRef]

117. Mariani, A.; Unich, A.; Minale, U. Combustion of hydrogen enriched methane and biogases containing hydrogen in a controlled auto-ignition engine. Appl. Sci. 2018, 8, 2667. [CrossRef]

118. Rocha, N.; Quintino, F.; Fernandes, E. $\mathrm{H}_{2}$ enrichment impact on the chemiluminescence of biogas/air premixed flames. Intern. J. Hydrog. Energy 2020, 45, 3233-3250. [CrossRef]

119. Fu, J.; Tang, C.; Jin, W.; Huang, Z. Effect of preferential diffusion and flame stretch on flame structure and laminar burning velocity of syngas Bunsen flame using OH-PLIF. Intern. J. Hydrog. Energy 2014, 39, 12187-12193. [CrossRef]

120. Buhre, B.J.; Elliott, L.K.; Sheng, C.D.; Gupta, R.P.; Wall, T.F. Oxy-fuel combustion technology for coal-fired power generation. Prog. Energy Combust. Sci. 2005, 31, 283-307. [CrossRef] 